\title{
New Soluble Polysiloxane Polymers Containing a Pendant Terdentate Aryldiamine Ligand Substituent Holding a Highly Catalytically Active Organometallic Nickel(II) Center
}

\author{
Lucia A. van de Kuil, ${ }^{\dagger, \ddagger}$ David M. Grove, ${ }^{*}$, Jan W. Zwikker,, \\ Leonardus W. Jenneskens, ${ }^{\ddagger}$ Wiendelt Drenth, ${ }^{\ddagger}$ and Gerard van Koten ${ }^{\dagger}$ \\ Debye Institute, Department of Metal-Mediated Synthesis, Utrecht University, Padualaan 8 , \\ 3584 CH Utrecht, The Netherlands, and Debye Institute, Department of Physical Organic \\ Chemistry, Utrecht University, Padualaan 8, 3584 CH Utrecht, The Netherlands
}

Received March 4, 1994. Revised Manuscript Received June 22, 1994 ${ }^{\otimes}$

\begin{abstract}
A new type of grafted polysiloxane polymer is described in which an aryldiamine substituent, $\left[\mathrm{C}_{6} \mathrm{H}_{3}\left(\mathrm{CH}_{2} \mathrm{NMe}_{2}\right)_{2}-2,6\right]^{-}$, provides a pendant terdentate ligand environment for a catalytically active (organo)nickel center. The novel strategy employed involves initial grafting of the aryl bromide 5-amino-2-bromo-1,3-bis[(dimethylamino)methyl]benzene into the side chain of poly((2-(chlorocarbonyl)ethyl)methylsiloxane) followed by nickel incorporation through an oxidative addition reaction with $\left[\mathrm{Ni}^{0}(\mathrm{COD})_{2}\right](\mathrm{COD}=$ cycloocta-1,5-diene $)$. Soluble polymers with different amounts of nickel incorporation have been prepared and characterized by NMR, FT-IR, and UV/vis spectroscopy as well as by differential scanning calorimetry (DSC) and gel permeation chromatography (GPC). These polymeric materials having an immobilized organonickel(II) center show good catalytic activity in the Kharasch addition reaction of polyhalogenated alkanes to alkenes that is of the same order of magnitude as for the comparable model organonickel(II) complex $\left[\mathrm{Ni}\left\{\mathrm{C}_{6} \mathrm{H}_{2}\left(\mathrm{CH}_{2} \mathrm{NMe}_{2}\right)_{2}-2,6-\mathrm{N}(\mathrm{H}) \mathrm{C}(\mathrm{O})-\right.\right.$ $\mathrm{Me}-4\} \mathrm{Br}]$.
\end{abstract}

\section{Introduction}

There is considerable activity in the development of methods for the immobilization of homogeneous transition-metal catalysts on organic polymers. Homogeneous catalysts offer the advantage of high selectivity and mild reactions conditions, while heterogeneous catalysts, although generally more active and less selective, are more durable and more easily separated from the reaction products. By anchoring a homogeneous catalyst to a polymer, the advantages of both types of catalysts can be combined. A number of successful approaches in this field of research have been reported ${ }^{1}$ and include examples such as polymer-bound nickel catalysts for the polymerization and/or oligomerization of ethylene ${ }^{1 \mathrm{~d}}$ and polymer-supported Ru(III) complexes for the hydrogenation of nitrobenzene. ${ }^{1 e}$

Recently, we reported that square-planar organonickel(II) complexes of the monoanionic aryldiamine ligand $\left[\mathrm{C}_{6} \mathrm{H}_{3}\left(\mathrm{CH}_{2} \mathrm{NMe}_{2}\right)_{2}{ }^{-2,6}\right]^{-}$(see Figure 1) ${ }^{2}$ are active homogeneous catalysts in the addition reaction of polyhalogenated alkanes to alkenes. ${ }^{3}$ Furthermore, we

${ }^{\dagger}$ Department of Metal-Mediated Synthesis.

₹ Department of Physical Organic Chemistry.

* To whom correspondence should be addressed.

${ }^{\circ}$ Abstract published in Advance ACS Abstracts, August 15, 1994.

(1) (a) Pittman, C. U., Jr. Comprehensive Organometallic Chemistry; Wilkinson, G., Ed.; Pergamon Press: Oxford, 1982; Vol. 8, pp 553611 and references therein. (b) Chaloner, P. A. Handbook of Coordination Catalysis in Organic Chemistry; Butterworth \& Co.: London, 1986. pp 121-129 (on hydrogenation), pp 329-330 (on hydrosilylation) and reference therein. (c) For polymer-supported nickel triad catalysts see: Chaloner, P. A. J. Organomet. Chem. 1992, 432, 387 and reference therein. (d) Braca, G.; Di Girolamo, M.; Raspolli Galletti, A. M.; Sbrana, G.; Brunelli, M.; Bertolini, G. J. Mol. Catal. 1992, 74, 421. (e) Shah, J. N.; Ram, R. N. J. Mol. Catal. 1992, 77, 235.
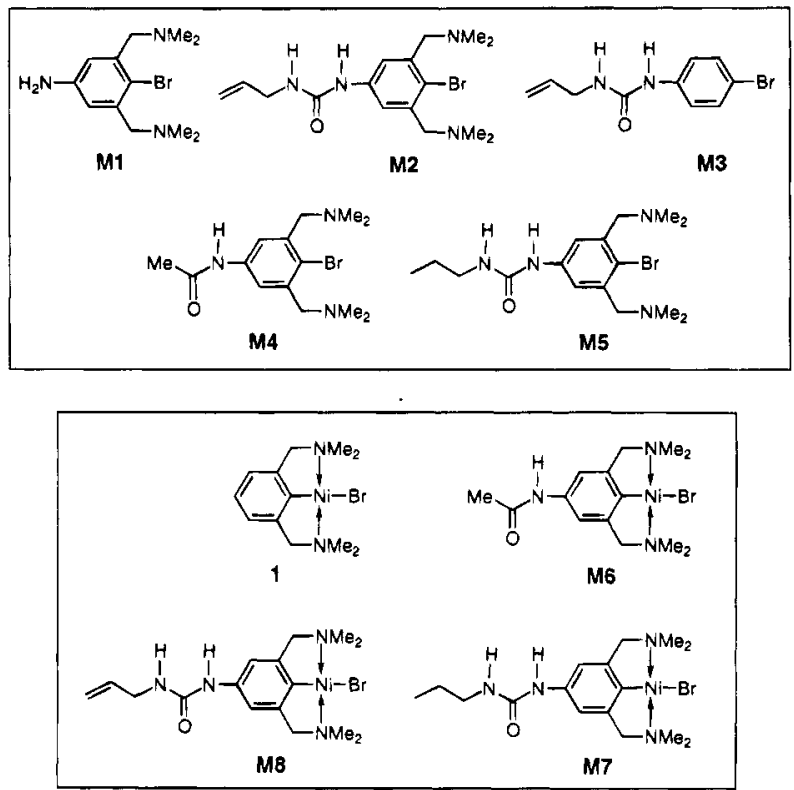

Figure 1. Aryl bromides M1-M5 and square-planar organonickel(II) complexes 1 and $\mathbf{M 6}-\mathbf{M 8}$ of the type $\left[\mathrm{Ni}\left\{\mathrm{C}_{6} \mathrm{H}_{2}\left(\mathrm{CH}_{2^{-}}\right.\right.\right.$ $\left.\left.\left.\mathrm{NMe}_{2}\right)_{2}-2,6-\mathrm{R}-4\right\} \mathrm{Br}\right]$

found that modification of this organic ligand system by introducing para substitutents on the aryl ring has

(2) (a) Grove, D. M.; van Koten, G.; Ubbels, H. J. C.; Zoet, R.; Spek, A. L. Organometallics 1984, 3, 1003. (b) van Beek, J. A. M.; van Koten, G.; Ramp, M. J.; Coenjaarts, N. C.; Grove, D. M.; Goublitz, K. Zoutberg, M. C.; Stam, C. H.; Smeets, W. J. J.; Spek, A. L. Inorg. Chem. 1991, 30,3059 .

(3) (a) Grove, D. M.; van Koten, G.; Verschuuren, A. H. M. J. Mol. Catal. 1988, 45, 169. (b) Grove, D. M.; Verschuuren, A. H. M.; van Koten, G.; van Beek, J. A. M. J. Organomet. Chem. 1989, 372, C1. 
a particularly marked influence on the physical properties of the corresponding $\mathrm{Ni}(\mathrm{II})$ complexes $^{4}$ and their catalytic properties. ${ }^{5}$

In this study we show how para substitution of the aryl ring also affords a route to an unprecedented type of soluble grafted polysiloxane polymer with an immobilized, C-bonded, organometallic system that has high catalytic activity in the Kharasch addition reaction.

\section{Results}

Synthesis of Grafted Polysiloxane Polymers. Our choice of a polysiloxane polymer for the purpose of anchoring a terdentate ligand based on $\left[\mathrm{C}_{6} \mathrm{H}_{3}\left(\mathrm{CH}_{2-}\right.\right.$ $\left.\left.\mathrm{NMe}_{2}\right)_{2}-2,6\right]^{-}$(and thereafter a catalytically active organometallic system) was based on its well-suited intrinsic properties, such as flexibility of the main chain, solubility in common organic solvents, and high degree of chemical inertness. Furthermore a wide variety of precursor organosilane compounds are available. To achieve our aim we decided to first graft an appropriately substituted aryl bromide (as ligand precursor) to a polysiloxane and at the last stage to introduce the nickel into the pendant aryldiamine environment by means of an oxidative addition reaction. In the two approaches we have developed (Schemes 1 and 2) an aryl bromide with a suitably reactive $\mathrm{NH}_{2}$ para substituent is employed, i.e., 5-amino-2-bromo-1,3-bis[(dimethylamino)methyl]benzene (M1), which was prepared by literature procedures. ${ }^{4}$

The first synthetic route, depicted in Scheme 1, involves the preparation of a polysiloxane polymer with side chains containing carboxylic acid groups. The latter, after conversion with thionyl chloride, can then be reacted with the $\mathrm{NH}_{2}$ function of $\mathbf{M 1}$ to provide a polymeric material in which the ligand precursor is present. To this end, we first prepared poly[(2-carboxyethyl)methylsiloxane] (P1), according to literature procedures, starting from (2-cyanoethyl)methyldichlorosilane. ${ }^{6}$ Under appropriate conditions, conversion of the $\mathrm{CN}$ group to a $\mathrm{COOH}$ group and polycondensation can be accomplished simultaneously; complete conversion of all $\mathrm{CN}$ groups was confirmed by IR and NMR analysis of a sample of $\mathbf{P 1}$ that had been esterified with $\mathrm{MeOH}$ to polymer P2. Reaction of P1 with thionyl chloride afforded poly[(2-(chlorocarbonyl)ethyl)methylsiloxane] (P3) in quantitative yield. This was further functionalized by reaction with the ligand precursor aryl bromide $\mathbf{M 1}$ in $\mathrm{CH}_{2} \mathrm{Cl}_{2}$ in the presence of triethylamine to afford P4 (and also for comparative purposes with aniline to afford P5, vide infra). Excess $\mathrm{MeOH}$ was used not only to remove any unreacted acid chloride groups by esterification but also to provide methoxy end-capped polysiloxanes. The polymers P4 and P5 were isolated and purified by precipitation in hexane and were obtained as pale yellow foams. Both materials were soluble in polar solvents such as $\mathrm{CH}_{2} \mathrm{Cl}_{2}, \mathrm{CHCl}_{3}$, and THF but insoluble in apolar solvents such as hexane.

4) van de Kuil, L A. Luitjes, H; Grove, D. M. Zwikker, J. W. van der Linden, J. G. M.; Roelofsen, A. M.; Jenneskens, L. W.; Drenth, W.; van Koten, G. Organometallics 1994, 13, 468.

(5) van de Kuil, L. A.; Groot, P. M. F. C.; van Rijswijk, J. P.; Grove, D. M.; Zwikker, J. W.; Jenneskens, L. W.; Drenth, W.; van Koten, G. J. Am. Chem. Soc., submitted.

(6) (a) Ohyanagi, M.; Ikeda, K.; Sekine, Y. Makromol. Chem., Rapid Commun. 1983, 4, 795. (b) Ohyanagi, M.; Nishide, H.; Suenaga, K. Tsuchida, E. Chem. Lett. 1987, 2309.
Scheme 1

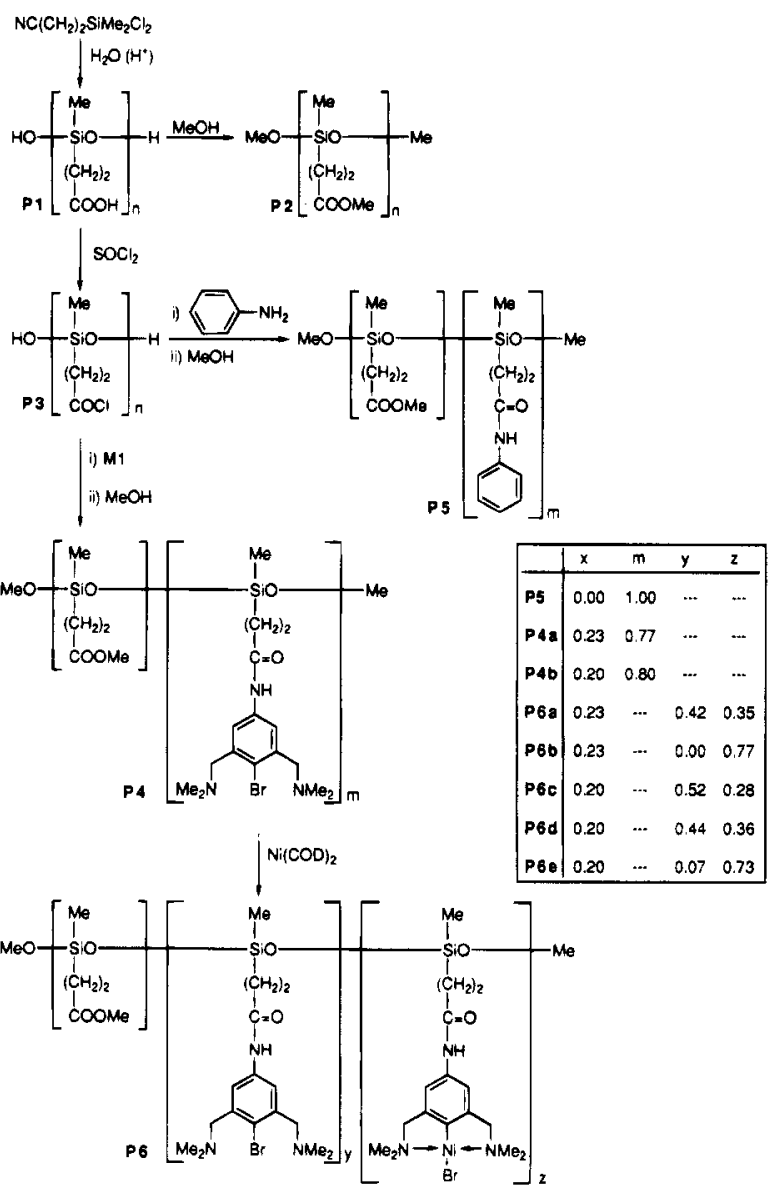

Scheme 2
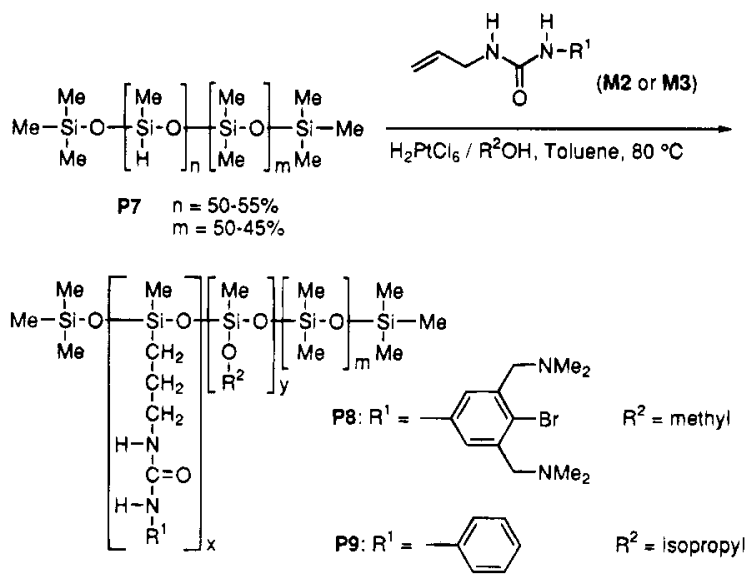

The polymer $\mathbf{P 4}$ containing the aryl bromide function is used, as described separately below, as the direct precursor to the desired nickel-containing polymeric materials P6.

In a second approach to the desired type of grafted polymer (Scheme 2) we decided to functionalize the $\mathrm{NH}_{2}$ group of M1 with a well-designed "spacer" having a functional group that is applicable for hydrosilylation with a commercially available organohydrosiloxane copolymer, (50-55\%)-methylhydro-(45-50\%)-dimethylsiloxane copolymer (P7).

The first step is the reaction of the amine group of M1 with allyl isocyanate to afford 5-( $N^{\prime}$-allylureido)-2bromo-1,3-bis[(dimethylamino)methyl]benzene (M2) that contains a terminal double bond (see eq 1). For com- 
parative purposes the compound 5-( $N^{\prime}$-allylureido)benzene (M3) was also synthesized from aniline and allyl isocyanate.

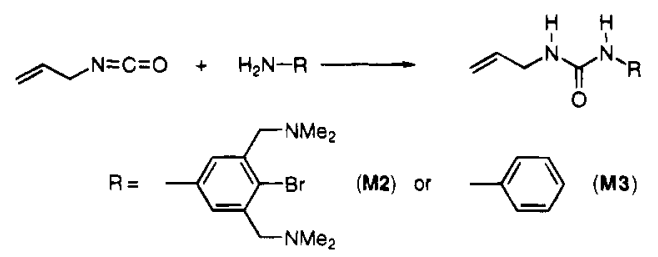

Subsequently M2 and M3 were grafted onto the polysiloxane (P7) via a hydrosilylation reaction with Speier's catalyst $\left(\mathrm{H}_{2} \mathrm{PtCl}_{6}\right.$ in methanol or isopropyl alcohol) to afford polymers $\mathbf{P 8}$ and $\mathbf{P 9}$, respectively (see Scheme 2). The polymers $\mathbf{P 8}$ and $\mathbf{P 9}$ were purified with preparative GPC. Both polymers are viscous yellow oils and are soluble in regular organic solvents. Unfortunately during the hydrosilylation reaction a number of undesired side reactions (vide infra) were more prevalent than we had anticipated, and, hence, these polymers after characterization were not employed further for nickel incorporation.

Nickel Incorporation. Incorporation of nickel into polymer P4 to afford polymer P6 was successfully achieved by an oxidative addition reaction of the aryl bromide function to $\left[\mathrm{Ni}^{0}(\mathrm{COD})_{2}\right] ;^{7}$ the method is similar to that used for the preparation of discrete organonickel(II) complexes from the closely related low molecular weight organic compounds $\mathrm{BrC}_{6} \mathrm{H}_{2}\left(\mathrm{CH}_{2} \mathrm{NMe}_{2}\right)_{2}-2,6-\mathrm{R}$ 4. ${ }^{4}$ A series of polymers of type $\mathbf{P 6}$ with differing nickel occupations, $\mathbf{P 6 a}-\mathbf{f}$, were obtained by reacting $\mathbf{P 4}$ with different equivalents of $\left[\mathrm{Ni}^{0}(\mathrm{COD})_{2}\right](\mathrm{COD}=1,5$-cylooctadiene; see inserted table in Scheme 1). The solubility of these polymers containing coordinated organometallic nickel(II) centers depends strongly on the amount of nickel that is incorporated. Although complete loading of the available terdentate ligand systems led to an insoluble polymer (P6b), lower loadings gave polymers (P6a,c-e), which are slightly soluble in $\mathrm{MeOH}$ but readily soluble in $\mathrm{CH}_{2} \mathrm{Cl}_{2}$ and benzene. Due to the nature of the organonickel(II) site ${ }^{3,4}$ these polymers are air-sensitive in solution and have to be handled under an inert atmosphere to prevent formation of Ni(III) species. $^{8}$

Discrete Organonickel Complexes. During this study three new mononuclear soluble organometallic complexes were prepared not only to prove the feasibility of nickel incorporation into aryl bromide bonds in the presence of specific para-positioned functionalities but also to serve as an aid in the spectroscopic characterization of the polysiloxane polymers and to afford model homogeneous catalysts whose catalytic activity could be compared with that of the new polymeric materials.

The oxidative addition of the aryl bromides M4, M5, and $\mathbf{M 2}$ with $\left[\mathrm{Ni}^{0}(\mathrm{COD})_{2}\right]$ affords in good yields the orange organonickel(II) complexes M6, M7, and M8, respectively (see Figure 1), which were characterized

(7) Inorganic Syntheses; Parshall, G. W., Ed.; Mcgraw-Hill: New York, 1974; Vol. XV, pp 5-9.

(8) Grove, D. M.; van Koten, G.; Zoet, R.; Murrall, N. W.; Welch, A J. J. Am. Chem. Soc. 1983, 105, 1379. Grove, D. M.; van Koten, G. Mul, P.; Zoet, R.; van der Linden, J. G. M.; Legters, J.; Schmitz, J. E. J.; Murall, N. W.; Welch, A. J. Inorg. Chem. 1988, 27, 2466. both spectroscopically and by elemental microanalysis (see Experimental Section).

Characterization of the Polysiloxane Polymers P1-6. The IR spectra of the functionalized polysiloxanes P1-P4 exhibit strong absorptions in the region 1130-1000 $\mathrm{cm}^{-1}$ assigned to the $\mathrm{Si}-\mathrm{O}-\mathrm{Si}$ backbone and a vibration at $1260 \mathrm{~cm}^{-1}$ due to $\mathrm{Si}-\mathrm{CH}_{3}$ functionalities. The position of the $\mathrm{C}=\mathrm{O}$ absorption is especially characteristic for the chemical modification of the side chain in the different polymers: $1710 \mathrm{~cm}^{-1}$ for the carboxylic acid function in $P 1,1740 \mathrm{~cm}^{-1}$ for the methyl ester in P2, $1800 \mathrm{~cm}^{-1}$ for the acid chloride in $\mathbf{P 3}$, and $1680 \mathrm{~cm}^{-1}$ (P4) and $1670 \mathrm{~cm}^{1}$ (P5) for the amide function. The IR spectra of P4 also exhibit absorptions at 2770,2820 , and $2860 \mathrm{~cm}^{-1}$, characteristic of the $\mathrm{NMe}_{2}$ unit of the aryldiamine system.

The polymers P4 and P5 afford ${ }^{1} \mathrm{H}$ and ${ }^{13} \mathrm{C}$ NMR spectra in agreement with the proposed molecular structures shown in Scheme 1. Although these polymers give broad ${ }^{1} \mathrm{H}$ NMR signals, their spectra do allow the assessment of the amount of methyl ester present. Polymer P4, prepared from aryl bromide $\mathbf{M 1}$ in two separate syntheses, contained $23 \%(\mathbf{P 4 a})$ and $20 \%(\mathbf{P 4 b})$ methyl ester, whereas polymer P5 prepared from aniline contained no methyl ester functionalities.

The polysiloxane polymers P2, P4, and P5 were also investigated by ${ }^{29} \mathrm{Si}$ NMR spectroscopy and two broad resonances, viz. at -20.0 and $-22.3 \mathrm{ppm}$ for $\mathbf{P 2}$ and at -19.9 and -21.9 ppm for P4 and P5, are found. The resonance near $-20 \mathrm{ppm}$ is attributed to cyclic species such as $[\mathrm{MeRSiO}]_{4},{ }^{9}$ and the other signal is attributed to methoxy end-capped species having a linear poly(dimethylsiloxane) chain. ${ }^{10}$

The functionalized polymers P1, P2, P4, and P5 were further characterized by DSC (differential scanning calorimetry) to gain insight into structural effects such as the dependence of flexibility of the main and side chains on steric hindrance and the bulk of the immobilized groups. The DSC curves of these polymers only show a glass transition temperature, $T_{\mathrm{g}}$ (see Table 1); no enthalpic effects are discernible, thus indicating that the polymers are amorphous.

The $T_{\mathrm{g}}$ of poly ((2-carboxyethyl)methylsiloxane) (P1) and the corresponding polymer with pendant methyl ester functionalities (P2) is -8.9 and $3.7^{\circ} \mathrm{C}$, respectively. After modification of the polysiloxane with either the aryl bromide ligand precursor M1 (to form P4) or aniline (to form P5) a considerable increase of the $T_{\mathrm{g}}$ is observed. Although the $T_{\mathrm{g}}$ 's are high for a regular silicone, it is known that grafting of side-chain functionalities can introduce favourable intra- or interchain interactions that raise the $T_{\mathrm{g}}$ considerably. ${ }^{6 \mathrm{~b}}$

The IR spectra of the polymers P6a-d containing the immobilized nickel centers are very similar to those of $\mathbf{P 4}$ and possess the characteristic band at $1680 \mathrm{~cm}^{-1}$ from the amide function as well as the strong absorptions in the region $1130-1000 \mathrm{~cm}^{-1}(\mathrm{Si}-\mathrm{O}-\mathrm{Si}$ backbone), a vibration at $1260 \mathrm{~cm}^{-1}\left(\mathrm{Si}-\mathrm{CH}_{3}\right.$ functions $)$ and absorptions at 2770,2820 , and $2860 \mathrm{~cm}^{-1}$ that originate from the $\mathrm{NMe}_{2}$ unit of the aryldiamine.

(9) Engelhardt, G.; Jancke, H.; Magi, M.; Pehk, T.; Lippma, E. J.

Organomet. Chem. 1971, 28, 293.
(10) Harris, R. K.; Kimber, B. J. Appl. Spectrosc. Rev. 1975, 10, 117. 
Table 1. Nickel Incorporation and Glass Transition Temperatures of Various Functionalized Polysiloxanes Polymers

\begin{tabular}{cccc}
\hline & \multicolumn{2}{c}{ nickel incorporation ${ }^{\alpha}(\%)$} & \\
\cline { 2 - 3 } polymer & ${ }^{1} \mathrm{H}$ NMR & elemental analysis & $T_{\mathrm{g}}{ }^{b}\left({ }^{\circ} \mathrm{C}\right)$ \\
\hline P1 & & & -8.9 \\
P2 & & & 3.7 \\
P4a & & & 60.7 \\
P4b & & & 59.7 \\
P5 & 46 & 100 & 64.9 \\
P6a & & $d$ \\
P6b $^{c}$ & 100 & 36 & $d$ \\
P6c $^{e}$ & 35 & 44 & $d$ \\
P6d $^{e}$ & 45 & 94 & $d$ \\
P6e $^{e}$ & 95 & & $d$
\end{tabular}

${ }^{a}$ Nickel incorporation of the functionalized polysiloxanes in percent of available bonded aryl bromide ligand precursor. ${ }^{b}$ Midpoint of glass transition determined by DSC. ${ }^{c}$ Functionalized polysiloxane batch with $23 \%$ methyl ester and $77 \%$ ligand precursor based on ${ }^{1} \mathrm{H}$ NMR. ${ }^{d}$ Due to decomposition no $T_{\mathrm{g}}$ observed in the temperature range $-20{ }^{\circ} \mathrm{C}$ to $+220{ }^{\circ} \mathrm{C}$. ${ }^{e}$ Functionalized polysiloxane batch with $20 \%$ methyl ester and $80 \%$ ligand precursor based on ${ }^{1} \mathrm{H}$ NMR.

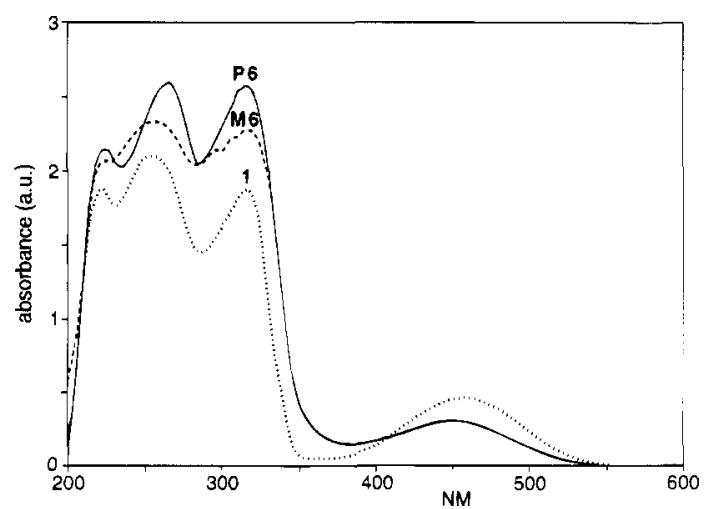

Figure 2. Solid-state UV/vis/NIR spectra (in $\mathrm{KBr}$ ) of the discrete organonickel(II) complexes (a) $\left[\mathrm{Ni}\left\{\mathrm{C}_{6} \mathrm{H}_{3}\left(\mathrm{CH}_{2} \mathrm{NMe}_{2}\right)_{2}\right.\right.$ $2,6\} \mathrm{Br}], 1$, (b) $\left[\mathrm{Ni}\left\{\mathrm{C}_{6} \mathrm{H}_{2}\left(\mathrm{CH}_{2} \mathrm{NMe}_{2}\right)_{2}-2,6-\mathrm{CH}_{3} \mathrm{C}(\mathrm{O}) \mathrm{N}(\mathrm{H})-4\right\} \mathrm{Br}\right]$, M6, and (c) a polymer $\mathbf{P 6}$ with immobilized nickel(II) centers.

The determination of the nickel content of polymers P6a-e by elemental microanalysis and ${ }^{1} \mathrm{H}$ NMR (Table 1) affords values that are in good agreement. The presence of the $\mathrm{Ni}$ (II) sites is readily confirmed by UV/ vis spectroscopy both in the solid state and in $\mathrm{CH}_{2} \mathrm{Cl}_{2}$ solution. In Figure 2 the spectra of discrete mononuclear $\mathrm{Ni}$ (II) complexes, [ $\left.\mathrm{Ni}\left\{\mathrm{C}_{6} \mathrm{H}_{3}\left(\mathrm{CH}_{2} \mathrm{NMe}_{2}\right)_{2}-2,6\right\} \mathrm{Br}\right]$ (1) and $\left.\left[\mathrm{Ni}_{2} \mathrm{C}_{6} \mathrm{H}_{2}\left(\mathrm{CH}_{2} \mathrm{NMe}_{2}\right)_{2}-2,6-(\mathrm{MeC}(\mathrm{O}) \mathrm{NH})-4\right\} \mathrm{Br}\right]$ (M6), and those of the corresponding funtionalized polymer $\mathbf{P 6}$ containing immobilized nickel(II) centers are shown. All three of these metal-containing systems exhibit an absorption at about $450 \mathrm{~nm}$ originating from the MLCT (metal-to-ligand charge transfer) band. ${ }^{3 b, 4}$ For the discrete mononuclear nickel(II) complexes as well as for the functionalized polymer P6 the absorptions in the region $200-320 \mathrm{~nm}$ can be assigned to electronic transitions of the ligand's aryl system. The close resemblance of these spectra indicate that aryldiamine complexation of the metal in the "free" organometallic complexes and in the functionalized polymer occurs in an identical way, i.e., the $\mathrm{Ni}$ (II) center is in a square-planar ligand environment. ${ }^{3}$

DSC data of polymers $\mathbf{P 6}$ show no $T_{\mathrm{g}}$ in the temperature region -20 to $220^{\circ} \mathrm{C}$. To investigate this further, the thermal decomposition of polymer P6d was studied with thermogravimetric analysis (TGA) under a nitro- gen atmosphere; at about $175^{\circ} \mathrm{C}\left(T_{\text {onset }}\right)$ loss of weight occurred, consistent with polymer decomposition. These results indicate that the $T_{\mathrm{g}}$ of these nickel-containing polymers is raised above their decomposition temperature. Since polymers P6 with medium-to-low nickel loading are readily soluble in organic solvents, there can be no extensive cross-linking present and therefore one can conclude that the incorporation of the nickel center leads to impairment of sidechain mobility, i.e., polymer flexibility, even when the amount of incorporated nickel is low.

Characterization of P8 and P9. The two polymers P8 and P9 (Scheme 2) obtained by hydrosilylation were analyzed by ${ }^{1} \mathrm{H}$ and ${ }^{13} \mathrm{C} \mathrm{NMR}$ spectroscopy. Besides the expected resonances for the immobilized aryl bromide ligand precursor, resonances that can be attributed to the alkyl group of the alcohol used in the reaction were also found. The NMR data and elemental microanalyses results indicate that in both P8 and P9 only 25$30 \%$ of the the available reactive $\mathrm{Si}-\mathrm{H}$ sites had reacted with the double bond of the spacer of M4 and M5, respectively, whereas $70-75 \%$ of these $\mathrm{Si}-\mathrm{H}$ sites had reacted with the alcoholic solvent to afford $\mathrm{Si}-\mathrm{OR}$ groups. The latter silane alcohol condensation reaction, in which hydrogen is a byproduct (eq 2), is known to

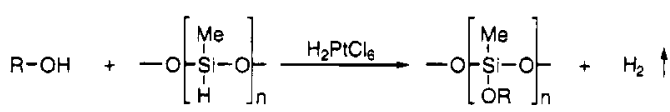

compete with hydrosilylation of the allylic functionality when a relatively large amount of $\mathrm{H}_{2} \mathrm{PtCl}_{6}$ catalyst is used. ${ }^{11}$ Note that the double bond of the spacer is also partially hydrogenated in this side reaction; it was possible to identify signals in the ${ }^{1} \mathrm{H}$ NMR spectrum of the reaction mixture before GPC (by comparison with 2-bromo-5-( $N^{\prime}$-propylureido)-1,3-bis[(dimethylamino)methyl]benzene, M5) that correspond to a methyl and a methylene group of a saturated alkyl chain from the former functionalized ligand system at $0.92 \mathrm{ppm}$ (triplet) and at $1.51 \mathrm{ppm}$ (sextet), respectively.

Catalysis. The discrete mononuclear organonickel(II) complexes of the type $\left[\mathrm{Ni}\left\{\mathrm{C}_{6} \mathrm{H}_{2}\left(\mathrm{CH}_{2} \mathrm{NMe}_{2}\right)_{2}-2,6-\mathrm{R}-\right.\right.$ 4 \} $\mathrm{Br}$ ], e.g., 1, are excellent homogeneous catalysts in the Kharasch addition reaction of polyhalogenated compounds to alkenes (eq 3). ${ }^{2,5}$ It is for their ability to

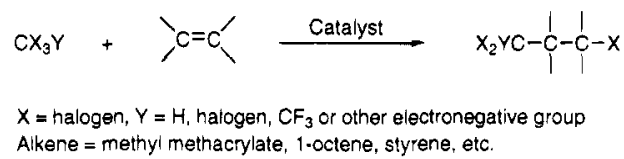

catalyze this type of reaction that we have tested the grafted polymers P6 containing immobilized organonickel(II) species and compared their catalytic activity directly with that of the discrete organonickel(II) complex $\left[\mathrm{Ni}\left\{\mathrm{C}_{6} \mathrm{H}_{2}\left(\mathrm{CH}_{2} \mathrm{NMe}_{2}\right)_{2}-2,6-(\mathrm{MeC}(\mathrm{O}) \mathrm{NH})-4\right\} \mathrm{Br}\right]$ (M6). Since the para substituent of the aryl ring in this type of catalyst influences the catalytic activity, ${ }^{4,5}$ we believe that the $\mathrm{MeC}(\mathrm{O}) \mathrm{NH}$ group in $\mathbf{M 6}$ is a good model for the amide bonding present in the anchoring chain of the polymeric system P6. In the tests of catalytic activity of polymers $\mathbf{P 6 c}-\mathbf{e}$ (all prepared from the same polymer batch $\mathbf{P 4 b}$ ) and of $\mathbf{M 6}$ the amount of catalyst

(11) Torrès, G.; Madec, P.-J.; Maréchal, E. Makromol. Chem. 1989, $190,2789$. 
Table 2. Catalytic Activity of Polymers P6 with Different Nickel Incorporation ${ }^{a}$

\begin{tabular}{ccccc}
\hline polymer & $\begin{array}{c}\mathrm{Ni} \\
\text { content }^{b}(\%)\end{array}$ & $\begin{array}{c}\text { amount of } \\
\text { polymer }(\mathrm{mg})\end{array}$ & $\begin{array}{c}\text { Ni sites } \\
\left(\times 10^{-5} \mathrm{~mol}\right)\end{array}$ & $\begin{array}{c}k \\
\left(\times 10^{5} \mathrm{~s}^{-1}\right)\end{array}$ \\
\hline P6c & 35 & 60.5 & 4.5 & 18.3 \\
P6d & 45 & 46.9 & 4.5 & 15.9 \\
P6e & 95 & 23.6 & 4.5 & 6.1 \\
M6 $^{c}$ & 100 & 17.6 & 4.5 & 17.5
\end{tabular}

${ }^{a}$ Reaction conditions: methyl methacrylate $(1.5 \mathrm{~mL}), \mathrm{CCl}_{4}(5$ $\mathrm{mL}$ ), and $\mathrm{CH}_{2} \mathrm{Cl}_{2}(6 \mathrm{~mL}){ }^{b}$ Percentage of available organic ligand systems that contain nickel, obtained from ${ }^{1} \mathrm{H}$ NMR and elemental analysis. ${ }^{c}$ Comparable discrete organonickel(II) complex.

was calculated such that in all reactions the same number of nickel(II) sites were present; the results are summarized in Table 2. Polymers P6c and P6d with the lower nickel loadings (corresponding to nickel occupations of the precursor ligand environments of $35 \%$ and $40 \%$, respectively) show catalytic reactivities that are equally good as that obtained for the free homogeneous "polymer-model" catalyst M6, and it can be concluded that our strategy for immobilizing $\mathrm{Ni}(\mathrm{II})$ centers for catalysis has been successful. In the case of polymer P6e with a higher level of nickel incorporation (90\% of precursor ligand environments occupied) its limited solubility led to the test reaction being carried out as a "heterogeneous" suspension yet, despite this deviation, this polymer too is also capable of catalysing the Kharasch addition reaction.

Although the polymer-based catalytic systems P6c and P6d are initially homogeneous orange-brown solutions, it should be noted that during catalysis the solubility of the polymer decreases and significant amounts of a pale purple material precipitate. Nevertheless this does not appreciably lower the activity of these immobilized catalyst systems! Because of this behavior and its relevance with respect to the mechanism of the Kharasch addition reaction we investigated and characterized this precipitate by FT-IR, UV/vis and ESR spectroscopy; the most important conclusion is that this material contains a paramagnetic $\mathrm{Ni}$ (III) center. Comparison of the fingerprint regions of the IR spectra of the starting polymer $\mathbf{P 6}$ and this purple precipitate (Figure 3) reveal few differences, thus the primary polymer structure, i.e., the main and side chains, of these materials are almost identical. From UV/vis spectroscopy it is evident that the principal difference lies with the metal center of the organonickel species, i.e., the MLCT band shifts from $450 \mathrm{~nm}$ for polymer $\mathbf{P 6}$ to $552 \mathrm{~nm}$ for the purple precipitate. Furthermore, upon exposure to air the purple precipitate turns green and the MLCT band shifts further to $587 \mathrm{~nm}$. To help interpret these results, corresponding data for the discrete organonickel complex $\left[\mathrm{Ni}^{\mathrm{II}}\left\{\mathrm{C}_{6} \mathrm{H}_{3}\left(\mathrm{CH}_{2} \mathrm{NMe}_{2}\right)_{2}-\right.\right.$ $2,6\} \mathrm{Br}], 1,3 \mathrm{~b}$ and the well-characterized dark green air-

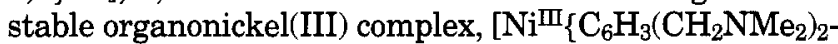
$\left.2,6\} \mathrm{Br}_{2}\right]^{8}$ have also been obtained and are collected in Table 3. These data show that the position of the MLCT band is indicative of the oxidation state of the metal center and that both the purple and green materials contain $\mathrm{Ni}$ (III) centers. For the purple precipitate this conclusion was further substantiated by X-band ESR spectroscopy. Both at ambient temperature and at $-196{ }^{\circ} \mathrm{C}$ a broad isotropic signal is found with a $\mathrm{g}$ tensor at $2.2038 \mathrm{G}$ and no hyperfine coupling; this value, similar to that found for $\left[\mathrm{Ni}{ }^{\mathrm{III}}\left\{\mathrm{C}_{6} \mathrm{H}_{3}\left(\mathrm{CH}_{2} \mathrm{NMe}_{2}\right)_{2}-2,6\right\} \mathrm{Br}_{2}\right]$
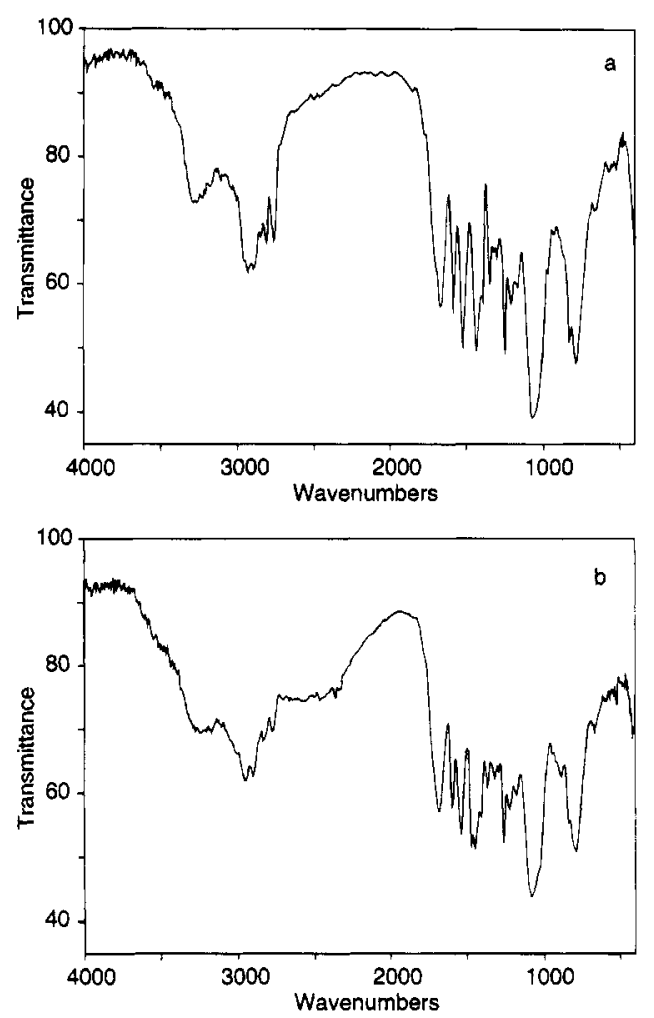

Figure 3. FT-IR spectra of polymer P6 (a) before and (b) use in the catalytic reaction.

Table 3. UV/Vis Data for the MLCT Band of Organonickel Complexes

\begin{tabular}{lcc}
\hline \multicolumn{1}{c}{ compound } & \multicolumn{2}{c}{$\lambda_{\max }(\mathrm{nm})$} \\
\cline { 2 - 3 } & $\begin{array}{c}\text { mononuclear } \\
\text { complex }^{a}\end{array}$ & $\begin{array}{c}\text { polymer } \\
\text { attached complex }\end{array}$ \\
\hline$\left[\mathrm{Ni}^{\mathrm{II}}(\mathrm{L}) \mathrm{Br}\right]$ & 457 & 450 \\
purple precipitate & $\mathbf{5 5 2 ^ { c }}$ & $\mathbf{5 5 2 ^ { d }}$ \\
green precipitate & & $\mathbf{5 8 7 ^ { e }}$ \\
{$\left[\mathrm{Ni}^{\mathrm{III}}(\mathrm{L}) \mathrm{Br}_{2}\right]$} & 564 & $f$
\end{tabular}

${ }^{a} \mathrm{~L}=\mathrm{C}_{6} \mathrm{H}_{3}\left(\mathrm{CH}_{2} \mathrm{NMe}_{2}\right)_{2}-2,6 .{ }^{b} \mathrm{~L}=$ corresponding polymer-bonded ligand system, polymer $-\mathrm{C}_{6} \mathrm{H}_{2}\left(\mathrm{CH}_{2} \mathrm{NMe}_{2}\right)_{2}-2,6$. ${ }^{c}$ From reaction with $\mathrm{CCl}_{4} .{ }^{18} d$ Purple material precipitated during catalytic reaction. ${ }^{e}$ Purple precipitate after exposure to air. $f$ Not measured.

at ambient temperature, ${ }^{8}$ is direct evidence for a metalbased radical species. Though the ligand set defining the Ni(III) coordination sphere of the purple solid is as yet not fully elucidated, one can clearly see that it is different to that in the dihalo pentacoordinate $\mathrm{Ni}$ (III) complexes $\left[\mathrm{Ni}^{\mathrm{III}}\left\{\mathrm{C}_{6} \mathrm{H}_{3}\left(\mathrm{CH}_{2} \mathrm{NMe}_{2}\right)_{2}-2,6\right\} \mathrm{X}_{2}\right](\mathrm{X}=\mathrm{Cl}, \mathrm{Br}$, I) which at $150 \mathrm{~K}$ have very distinctive multiline ESR spectra due to the presence of halide hyperfine splitting.

\section{Discussion}

Synthesis. There are several reports ${ }^{12-15}$ in which polysiloxanes have been used as polymeric supports for

(12) Kreuder, W.; Ringsdorf, H. Makromol. Chem., Rapid Commun. $1983,4,807$.

(13) (a) Nemoto, N.; Asano, M.; Asakura, T.; Ueno, Y.; Ikeda, K.; Takamiya, N. Makromol. Chem. 1989, 190, 2303. (b) Nemoto, N.; Asano, M.; Asakura, T.; Hongo, I.; Ueno, Y.; Ikeda, K.; Takamiya, N. J. Inorg. Organomet. Polym. 1991, 2, 211. (c) Nemoto, N.; Asakura, T.; Tobita, K.; Ueno, Y.; Ikeda, K.; Takamiya, N.; Ohkatsu, Y. J. Mol. Catal. 1991, 70, 151.

(14) Nemoto, N.; Yotsuya, T.; Aoyagi, S.; Ueno, Y.; Ikeda, K.; Takamiya, N. Makromol. Chem. 1990, 191, 479.

(15) Zeldin, M.; Fife, W. K.; Tian, C.; Xu, J. Organometallics 1988 7,470 . 
different types of catalysts, e.g., metallophthalocyanines, ${ }^{13}$ imidazoyl groups, ${ }^{14}$ or oxypyridinyl groups. ${ }^{15}$ The catalytic polysiloxane polymers P6 that we have prepared are a new class of material with an interesting set of properties resulting from the use of the very versatile $N, C, N$ coordinating $\mathrm{C}_{6} \mathrm{H}_{2}\left(\mathrm{CH}_{2} \mathrm{NMe}_{2}\right)_{2}-2,6-\mathrm{R}-4$ ligand. ${ }^{16}$ One of the most important characteristics of P6 polymers is that they are true organometallic materials in which the square-planar metal center is held by a direct $\mathrm{M}-\mathrm{C}_{\text {aryl }} \sigma$-bond, with a halide atom and and two chelating amino substituents completing its coordination sphere. The successful strategy for preparing polymer-bound transition metal (in this case nickel) centers using this ligand can now be extended to related systems where a small terdentate (or polydentate) cavity can firmly hold a specific metal (or metals) by the combination of a $\mathrm{M}-\mathrm{C} \sigma$ bond with an appropriate number of $\mathrm{N}$ (and other) donor atoms. A significant advantage of grafting a preorganized ligand set onto one polymer site is that when a metal center is introduced it becomes coordinated by one intact ligand. In this way one excludes undesired cross-linking which can occur when a metal center coordinates to more than one (usually monodentate) ligand at different polymer sites. It is also implicit in this type of strategy that the nature of the ligand array, in particular the presence of a metal-carbon $\sigma$ bond, should provide materials from which metal leaching is minimal.

It is worthwhile to comment here on some practical aspects regarding the preparation of these materials which are of particular relevance to future developments. These are the extent to which the precursor ligand could be grafted into the polymer, the molecular weight of the polymer and the degree of metal loading that is possible. The maximum extent of aryl bromide introduction we achieved into the side chain of poly[(2(chlorocarbonyl)ethyl)methylsiloxane] (P3) when preparing P4 corresponds to about $80 \%$ of the theoretically available reactive sites, and this is certainly a consequence of steric hindrance exerted by the bulkiness of the ligand precursor system. Similar steric effects were reported by Nemoto et al. ${ }^{14}$ upon grafting P3 with imidazoyl groups. GPC analysis seemed to indicate that the molecular weight of $\mathbf{P 4}$ containing the aryldiamine ligand system was considerably lower than that of P2, a representative precursor polymer of poly((2-carboxyethyl)methylsiloxane) (P1; see Experimental Section). To establish whether or not this decrease was due to hydrolysis of $\mathrm{Si}-\mathrm{O}-\mathrm{Si}$ bonds of the polysiloxane during the conversion of the carboxy groups of P1 to the chlorocarbonyl groups of P3, ${ }^{6 \mathrm{~b}}$ a reference polymer $\mathbf{P 5}$ containing side chains functionalized with aniline was made from P3. Since GPC of P5 showed a similar molecular weight distribution to that of the precursor polymer P2 we could deduce that polymer degradation does not occur. We conclude therefore that the anomalously low molecular weight obtained with GPC for polymer P4 can be attributed to adsorption phenomena, presumably due to the presence of the amino functionalities of the aryldiamine system. Finally, one should notice that the incorporation of nickel into the polymers $\mathbf{P 4}$ to form $\mathbf{P 6}$ through an oxidative addition reaction with aryl bromide functions and $\left[\mathrm{Ni}^{0}(\mathrm{COD})_{2}\right]$ is not stoichiometric; however, control of nickel incorporation

(16) van Koten, G. Pure Appl. Chem. 1989, 61, 1681.

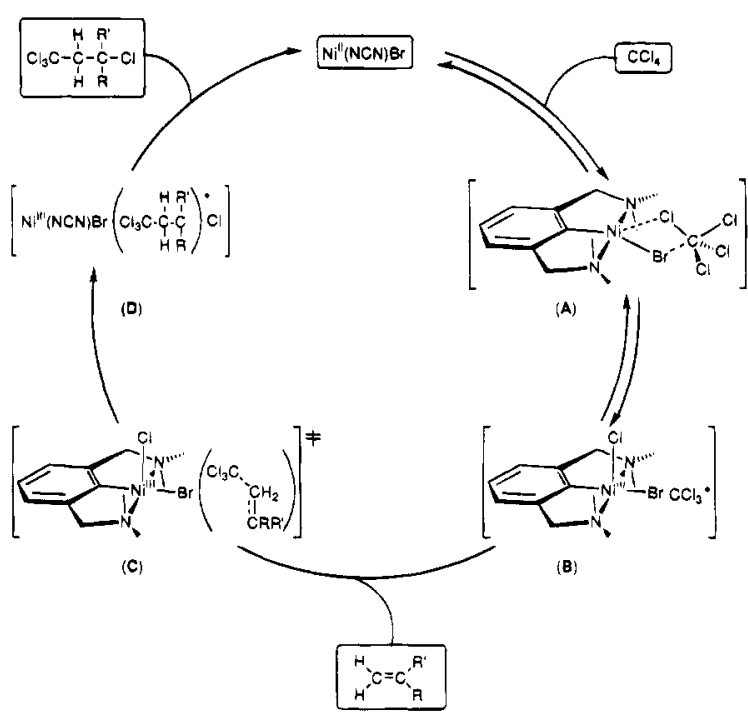

Figure 4. Postulated mechanism for the 1:1 addition reaction of $\mathrm{CCl}_{4}$ to an alkene in the presence of mononuclear organonickel(II) complex [Ni $\left.\left\{\mathrm{C}_{6} \mathrm{H}_{3}\left(\mathrm{CH}_{2} \mathrm{NMe}_{2}\right)_{2}-2,6\right\} \mathrm{Br}\right], 1$ (=Ni(NCN)$\mathrm{Br}$ ).

is possible by changing the relative amounts of $\left[\mathrm{Ni}^{0}-\right.$ $\left.(\mathrm{COD})_{2}\right]$ used. One can see here the effects of the constraints being exerted by the generation of an organized square-planar ligand environment, and this is also reflected in the fact that the solubility of the polymer-bound catalysts $\mathbf{P 6}$ decreases with increasing nickel incorporation.

Catalysis. The polymers P6 containing a pendant aryldiamine ligand system that holds an immobilized nickel(II) center are catalytically active in the Kharasch addition reaction and in the case of the soluble polymers P6c and P6d their activity is similar to that of the discrete organonickel(II) complex M6. This shows that when the nickel incorporation is not too high, the polymers are still relatively flexible and soluble and that the active sites are very readily accessible from the bulk solution; in this and other aspects it is clear that both the polymeric and the homogeneous catalytic systems behave similarly. We have investigated various aspects of the Kharasch addition reaction with mononuclear nickel complexes $\left[\mathrm{NiI}^{\mathrm{II}}\left\{\mathrm{C}_{6} \mathrm{H}_{2}\left(\mathrm{CH}_{2} \mathrm{NMe}_{2}\right)_{2}-2,6-\mathrm{R}-4\right\} \mathrm{X}\right]^{5}$ and related chiral species, ${ }^{17}$ and our proposed mechanism based on 1 is outlined in Figure 4. It was found in the mechanistic investigation ${ }^{5}$ that the kinetics with $\mathrm{CCl}_{4}$ are of the Michaelis-Menten type, and this indicates that the catalyst can be saturated with $\mathrm{CCl}_{4}$. Thus in the proposed mechanism the organonickel(II) complex first reacts reversibly with $\mathrm{CCl}_{4}$ to give an encounter complex intermediate $\mathbf{A}$ which, via a one-electron transfer, can afford a $\mathrm{Ni}$ (III)-based intermediate B. [It should be stressed that the illustrated structures represent simplifications of two extreme situations, namely, $\mathrm{Ni}$ (II) and Ni(III) states, of the interaction between complex 1 and $\mathrm{CCl}_{4}$; they do not take into account either stabilizing (alkene) donor/solvent interactions or possible ionic forms attainable by halide dissociation in the polar reaction medium.] The rate-determining step in the catalytic cycle is believed to be the reaction of intermediate $\mathbf{B}$ with an alkene to form $\mathbf{C}$.

(17) van de Kuil, L. A.; Veldhuizen, Y. S. J.; Grove, D. M.; Zwikker, J. W.; Jenneskens, L. W.; Drenth, W.; Smeets, W. J. J.; Spek, A. L.; van Koten, G. Recl. Trav. Chim. Pays-Bas 1994, 113, 26.7. 
In the case of the soluble $\mathbf{P 6}$ polymers a surprising feature was the formation of a purple precipitate during the catalytic reaction that did not seem to influence the catalytic activity; i.e., the metal sites in the precipitate must still be readily accessible since the rate-determining step in the catalytic cycle-the reaction with an alkene-is not affected. This material was investigated in conjunction with a related purple compound obtained from the discrete organonickel(II) complex by reaction with $\mathrm{CCl}_{4},{ }^{18}$ with a view to establishing whether they might indeed represent intermediates in the proposed catalytic cycle.

Both purple materials have virtually identical ESR, $I R$, and UV/vis data that are consistent with the presence of an organonickel(III) species which we believe could be a form of B (Figure 4) that has significant ionic character. In the homogeneous catalytic system such an ionic intermediate would remain in solution and not disclose itself, but in the polymer bound systems $\mathbf{P 6}$ the ionicity would cause a decrease in polymer solubility and lead to precipitation. The nature of the precipitated polymer material is still being investigated, but the feasibility of our proposal is illustrated by the recent isolation and structural characterization of a novel octahedrally coordinated cationic $\mathrm{Ni}(\mathrm{III})$ species $\left[\mathrm{Ni}\left\{\mathrm{C}_{6} \mathrm{H}_{3}\left(\mathrm{CH}_{2} \mathrm{Z}\right)_{2}-2,6\right) \mathrm{X}\right]^{+}(\mathrm{Z}=2$ - $(S)-2$ (isopropoxycarbonyl)-1-pyrrolidinyl); ${ }^{19 a}$ we have reported neutral six-coordinate organonickel(III) species earlier. ${ }^{19 b}$

A final point worth mentioning is that the formation of a catalytically active precipitate from our originally homogeneous solution may provide us with an easy way to recover and reuse the polymeric material and further studies bearing upon catalyst recycling are current.

\section{Conclusions}

This study shows that the organic terdentate ligand system $\left[\mathrm{C}_{6} \mathrm{H}_{2}\left(\mathrm{CH}_{2} \mathrm{NMe}_{2}\right)_{2}-2,6-\mathrm{R}-4\right]^{-}$can be introduced into the side chain of poly([2-(chlorocarbonyl)ethyl]methylsiloxane) as an aryl bromide precursor and that incorporation of nickel into the ligand system is possible using an oxidative addition reaction with $\left[\mathrm{Ni}^{0}(\mathrm{COD})_{2}\right]$ $(\mathrm{COD}=$ cycloocta-1,5-diene $)$. Polymers with different amounts of nickel incorporation have been prepared, and these materials with immobilized $\mathrm{Ni}$ (II) centers show good catalytic activity in the Kharasch addition reaction of polyhalogenated alkanes to alkenes.

Our methodology for grafting to a polymer what can be seen as a catalytic site in a small polydentate cavity has the major advantage of avoiding the problem of polymer cross-linking resulting from a metal coordinating to more than one ligand at different polymer sites. The large number of metals that can be coordinated by arylamine polydentate ligands $\mathrm{s}^{16,20}$ and related arylbisphoshine terdentate ligands ${ }^{21}$ points to this approach

(18) The reaction of a discrete mononuclear nickel(II) complex, [Ni$\left.\left\{\mathrm{C}_{6} \mathrm{H}_{3}\left(\mathrm{CH}_{2} \mathrm{NMe}_{2}\right)_{2}-2,6\right\} \mathrm{Br}\right]$, with $\mathrm{CCl}_{4}$ under a nitrogen atmosphere afforded a solution from which was isolated an unknown purple solid by slow evaporation of the solvent (several days). This compound was used for comparison in UV/vis spectroscopy with the obtained polymeric purple precipitate obtained from the catalytic reaction mixture.

(19) (a) van de Kuil, L. A.; Veldhuizen, Y. S. J.; Grove, D. M. Zwikker, J. W.; Jenneskens, L. W.; Drenth, W.; Smeets, W. J. J.; Spek, A. L.; van Koten, G. J. Organomet. Chem., submitted. (b) Grove, D. M.; van Koten, G.; Mul, W. P.; van der Zeijden, A. A. H.; Terheijden, J.; Zoutberg, M. C.; Stam, C. H. Organometallics 1986, 5, 322. as being an interesting starting point for the development of new types of polymer-based catalyst systems.

\section{Experimental Section}

General Techniques. All reagents were commercially available and used without further purification except for $\left[\mathrm{Ni}^{0}\right.$ $\left.(\mathrm{COD})_{2}\right](\mathrm{COD}=$ cycloocta-1,5-diene $)$ which was synthesized according to a literature procedure. ${ }^{?}$ The organohydrosiloxane copolymer (50-55\%)-methylhydro-(45-50\%)-dimethylsiloxane copolymer (PS 122.5), P7, was obtained from Petrarch. Solvents were dried and freshly distilled before use. All reactions (including catalysis) and manipulations of air-sensitive nickel complexes were carried out under a nitrogen atmosphere using Schlenk techniques. ${ }^{1} \mathrm{H}$ NMR and ${ }^{13} \mathrm{C}$ NMR spectra were recorded on a Bruker AC 300 spectrometer operating at 300.12 and $75.47 \mathrm{MHz}$, respectively. Chemical shifts are given relative to TMS. Abbreviations used are s singlet, d doublet, $\mathrm{t}$ triplet, q quartet, $\mathrm{m}$ multiplet, and br broad. UV/vis spectra were measured on a Varian Cary 1. Solid-state UV/vis/NIR spectra were measured on a Varian Cary 5 dispersive spectrometer using a Harrick diffuse reflection accessory (Praying Mantis); the samples were diluted with optically pure potassium bromide. Fourier transform infrared spectra were recorded on a Mattson Galaxy Series FTIR 5000 spectrometer. For the thermogravimetric experiments a Perkin Elmer TGS-2 equipped with an autobalance AR-2 was used (temperature program $50 \rightarrow 800^{\circ} \mathrm{C}$, heating rate $20^{\circ} \mathrm{C} \mathrm{min}-1$; TG curves) and on a Mettler/Toledo DSC $12 \mathrm{E}$ (temperature program -20 $\rightarrow 220^{\circ} \mathrm{C}$, heating rate $10^{\circ} \mathrm{C} \mathrm{min}-1 ; D S C$ curves). Molecular weight distributions (number-average molecular weight $M_{n}$ and weight-average molecular weight $M_{\mathrm{w}}$ ) were determined with gel permeation chromatography (GPC, mixed-bed column; eluent, THF or $\mathrm{CHCl}_{3}$; detection method, refractive index or UV/vis at $254 \mathrm{~nm}$, reference Polystyrene standards). Elemental analyses were carried out by Mikroanalytisches Laboratorium Dornis und Kolbe, Mülheim a.d. Ruhr, Germany

Catalytic Measurements. A solution of an alkene (1.5 $\mathrm{mL}, 14 \mathrm{mmol})$ and $\mathrm{CCl}_{4}(5 \mathrm{~mL}, 51.7 \mathrm{mmol})$ in $\mathrm{CH}_{2} \mathrm{Cl}_{2}(5 \mathrm{~mL})$ was degassed three times using the freeze-pump-thaw method and brought under a nitrogen atmosphere. The immobilized catalyst was dissolved in $\mathrm{CH}_{2} \mathrm{Cl}_{2}$ and subsequently added through a septum to the alkene/ $\mathrm{CCl}_{4}$ solution kept at $25^{\circ} \mathrm{C}$ with a thermostat. The reaction was monitored by withdrawing samples from the reaction mixture and analysing them by GLC (Varian 3400 gas chromatograph; CP Sils; $105^{\circ} \mathrm{C}, 3 \mathrm{~min}, 20^{\circ} \mathrm{C} / \mathrm{min}, 245^{\circ} \mathrm{C}, 5 \mathrm{~min}$ ); dodecane was used as an internal standard.

Synthesis of the Low Molecular Weight Organic Com. pounds and Discrete Organonickel(II) Complexes. 5-Amino-2-bromo-1,3-bis[(dimethylamino)methyl]benzene (M1). This compound was synthesized according to a literature procedure. ${ }^{4}{ }^{1} \mathrm{H} \mathrm{NMR}\left(\mathrm{CDCl}_{3}\right) \delta 2.29\left(\mathrm{~s}, 12 \mathrm{H}, \mathrm{NCH}{ }_{3}\right), 3.45(\mathrm{~s}$, $\left.4 \mathrm{H}, \mathrm{ArCH} \mathrm{H}_{2}\right), 3.68\left(\mathrm{br} \mathrm{s}, 2 \mathrm{H}, \mathrm{NH}_{2}\right), 6.70(\mathrm{~s}, 2 \mathrm{H}, \mathrm{ArH}) .{ }^{13} \mathrm{C} \mathrm{NMR}$ $\left.\left(\mathrm{CDCl}_{3}\right) \delta 45.96\left(\mathrm{NCH}_{3}\right), 64.06(\mathrm{ArCH})_{2}\right), 114.88(\{\mathrm{Ar}\} \mathrm{CBr})$, $116.26(\{\mathrm{Ar}\} \mathrm{CH}), 139.41\left(\{\mathrm{Ar}\} \mathrm{CCH}_{2} \mathrm{~N}\right), 145.62\left(\{\mathrm{Ar}\} \mathrm{CNH}_{2}\right)$.

5-( $N^{\prime}$-Allylureido)-2-bromo-1,3-bis[(dimethylamino)methyl]benzene (M2). Allyl isocyanate $(3.65 \mathrm{~g}, 43.93 \mathrm{mmol})$ in $\mathrm{CH}_{2-}$ $\mathrm{Cl}_{2}(6 \mathrm{~mL})$ was added to a stirred solution of 5-amino-2-bromo1,3-bis[(dimethylamino)methyl]benzene (M1, $12.03 \mathrm{~g}, 42.03$ $\mathrm{mmol})$ in $\mathrm{CH}_{2} \mathrm{Cl}_{2}(10 \mathrm{~mL})$ with the reaction temperature maintained below $10^{\circ} \mathrm{C}$. Subsequently, the reaction mixture was stirred for $4 \mathrm{~h}$ at ambient temperature. The product was isolated as a pale yellow solid by removing the volatiles in vacuo; $15.49 \mathrm{~g}, 41.94 \mathrm{mmol}$ (99\% yield): $\mathrm{mp} 137-141{ }^{\circ} \mathrm{C}$. ${ }^{1} \mathrm{H}$ $\mathrm{NMR}\left(\mathrm{CD}_{3} \mathrm{OD}\right) \delta 2.28\left(\mathrm{~s}, 12 \mathrm{H}, \mathrm{NCH}_{3}\right), 3.57\left(\mathrm{~s}, 4 \mathrm{H}, \mathrm{ArCH} \mathrm{H}_{2}\right)$, $3.80\left(\mathrm{~m}, 2 \mathrm{H}, \mathrm{NCH}_{2}\right), 5.15\left(\mathrm{~m}, 2 \mathrm{H}, \mathrm{CH}_{2}\right), 5.89(\mathrm{~m}, 1 \mathrm{H}, \mathrm{CH}), 7.43$ $(\mathrm{s}, 2 \mathrm{H}, \mathrm{ArH}) .{ }^{13} \mathrm{C}$ NMR ( $\left.\mathrm{CD}_{3} \mathrm{OD}\right) \delta 43.29\left(\mathrm{NCH}_{2}\right), 45.74$ $\left.\left(\mathrm{NCH}_{3}\right), 64.69(\mathrm{ArCH})_{2}\right), 115.75\left(\mathrm{CH}_{2}\right), 120.66(\{\mathrm{Ar}\} \mathrm{CBr}), 121.95$ $(\{\mathrm{Ar}\} \mathrm{CH}), 136.65(\mathrm{CH}), 139.53\left(\{\mathrm{Ar}\} \mathrm{CCH}_{2} \mathrm{~N}\right), 140.17(\{\mathrm{Ar}\}-$

(20) Abbenhuis, H. C. L.; Feiken, N.; Grove, D. M.; Jastrzebski, J. T. B. H.; Kooijman, H.; van der Sluis, P.; Smeets, W. J. J.; Spek, A. L.; van Koten, G. J. Am. Chem. Soc. 1992, 114, 9773.

(21) Gorla, F.; Venanzi, L. M.; Albinati, A. Organometallics 1994 13,43 and references therein. 
$\mathrm{CN}), 157.78(\mathrm{CO}) . \quad \mathrm{IR}\left(\mathrm{KBr}, \mathrm{cm}^{-1}\right): 3340(\mathrm{NH}), 3090\left(\mathrm{CH}_{2}\right)$,

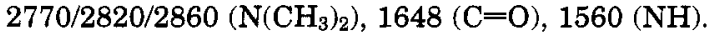

5 -( $N^{\prime}$-Allylureido)benzene (M3). The product was synthesized employing the procedure for $\mathbf{M 2}$ above from allyl isocyanate $(0.49 \mathrm{~g}, 5.9 \mathrm{mmol})$ and aniline $(0.55 \mathrm{~g}, 5.9 \mathrm{mmol})$, affording a pale yellow solid, $0.95 \mathrm{~g}, 5.4 \mathrm{mmol}(92 \%$ yield): $\mathrm{mp}$ $102{ }^{\circ} \mathrm{C}$. ${ }^{1} \mathrm{H} \mathrm{NMR}\left(\mathrm{CDCl}_{3}\right) \delta 3.86\left(\mathrm{~m}, 2 \mathrm{H}, \mathrm{NCH}_{2}\right), 5.18(\mathrm{~m}, 2 \mathrm{H}$, $\left.\mathrm{CH}_{2}\right), 5.85(\mathrm{~m}, 1 \mathrm{H}, \mathrm{CH}), 7.08(\mathrm{~m}, 1 \mathrm{H}, \mathrm{ArNH}), 7.28(\mathrm{~m}, 5 \mathrm{H}$, $\mathrm{ArH}) .{ }^{13} \mathrm{C}$ NMR $\left(\mathrm{CDCl}_{3}\right) \delta 42.60\left(\mathrm{NCH}_{2}\right), 115.72\left(\mathrm{CH}_{2}\right), 120.76$ $\left(\{\mathrm{Ar}\} C_{\text {ortho }}\right), 123.51\left(\{\mathrm{Ar}\} C_{\text {para }}\right), 129.11\left(\{\mathrm{Ar}\} C_{\text {meta }}\right), 134.95(\mathrm{CH})$, $138.65(\{\mathrm{Ar}\} \mathrm{CN}), 156.41(\mathrm{CO})$. IR $\left(\mathrm{KBr}, \mathrm{cm}^{-1}\right) 3100(\mathrm{NH}), 3020$ $\left(\mathrm{CH}_{2}\right), 1630(\mathrm{C}=0), 1560(\mathrm{NH})$.

5-(Acetylamino)-2-bromo-1,3-bis[(dimethylamino)methyl]benzene (M4). This compound was synthesized according to a literature procedure ${ }^{4}{ }^{1} \mathrm{H}$ NMR $\left(\mathrm{CDCl}_{3}\right) \delta 2.14\left(\mathrm{~s}, 3 \mathrm{H}, \mathrm{CH}_{3} \mathrm{C}\right.$ (O) $), 2.29\left(\mathrm{~s}, 12 \mathrm{H}, \mathrm{NCH}_{3}\right) 3.51\left(\mathrm{~s}, 4 \mathrm{H}, \mathrm{ArCH}_{2}\right) 7.48(\mathrm{br} \mathrm{s}, \mathrm{H}$ $\mathrm{NH}), 7.52(\mathrm{~s}, 2 \mathrm{H}, \mathrm{ArH}) .{ }^{13} \mathrm{C} \mathrm{NMR}\left(\mathrm{CDCl}_{3}\right) \delta 24.02\left(\mathrm{CH}_{3} \mathrm{C}(\mathrm{O})\right)$, $45.70\left(\mathrm{NCH}_{3}\right), 64.61(\mathrm{ArCH}), 122.41(\{\mathrm{Ar}\} \mathrm{CBr}), 122.92(\{\mathrm{Ar}\}-$ $\mathrm{CH}), 139.08(\{\mathrm{Ar}\} \mathrm{CN}(\mathrm{H})), 139.59\left(\{\mathrm{Ar}\} \mathrm{CCH}_{2} \mathrm{~N}\right) 171.61(\mathrm{C}(\mathrm{O}))$.

2-Bromo-5-( $N^{\prime}$-propylureido)-1,3-bis[(dimethylamino)methyl]benzene (M5). This product was synthesized employing the procedure for M2 above from propyl isocyanate (1.03 g, 12.10 $\mathrm{mmol}$ ) and 5-amino-2-bromo-1,3-bis[(dimethylamino)methyl]benzene M1 (3.04 g, $10.62 \mathrm{mmol}$ ) and isolated as an off-white solid; $3.68 \mathrm{~g}, 9.91 \mathrm{mmol}$ ( $93 \%$ yield): $\mathrm{mp} 138-141{ }^{\circ} \mathrm{C} .{ }^{1} \mathrm{H}$ NMR $\left(\mathrm{CD}_{3} \mathrm{OD}\right) \delta 0.93\left(\mathrm{t}, 3 \mathrm{H}, \mathrm{CH}_{3},{ }^{3} \mathrm{~J}=7 \mathrm{~Hz}\right), 1.52\left(\mathrm{~m}, 2 \mathrm{H}, \mathrm{CH}_{2}\right)$, $2.29\left(\mathrm{~s}, 12 \mathrm{H}, \mathrm{NCH}_{3}\right), 3.13\left(\mathrm{t}, 2 \mathrm{H}, \mathrm{NCH}_{2},{ }^{3} \mathrm{~J}=7 \mathrm{~Hz}\right), 3.58(\mathrm{~s}$, $\left.4 \mathrm{H}, \mathrm{ArCH}_{2}\right), 7.41(\mathrm{~s}, 2 \mathrm{H}, \mathrm{ArH}) .{ }^{13} \mathrm{C} \mathrm{NMR}\left(\mathrm{CD}_{3} \mathrm{OD}\right) \delta 11.66$ $\left(\mathrm{CH}_{3}\right), 24.37\left(\mathrm{CH}_{2}\right), 42.64\left(\mathrm{NCH}_{2}\right), 45.59\left(\mathrm{NCH}_{3}\right), 64.66(\mathrm{ArCH})$, $120.58(\{\mathrm{Ar}\} \mathrm{CBr}), 121.95(\{\mathrm{Ar}\} \mathrm{CH}), 139.50\left(\{\mathrm{Ar}\} \mathrm{CCH}_{2} \mathrm{~N}\right)$, $140.24(\{\mathrm{Ar}\} C \mathrm{~N}), 158.07(\mathrm{CO}) . \mathrm{IR}\left(\mathrm{KBr}, \mathrm{cm}^{-1}\right) 3340(\mathrm{NH})$, $2770 / 2820 / 2860\left(\mathrm{~N}\left(\mathrm{CH}_{3}\right)_{2}\right), 1648(\mathrm{C}=\mathrm{O}), 1560(\mathrm{NH})$

Nickel(II) Complex from 5-(Acetylamino)-2-bromo-1,3-bis[(dimethylamino)methyl]benzene (M6). This complex was synthesized according to a literature procedure, ${ }^{3,4}$ starting from 5-(acetylamino)-2-bromo-1,3-bis[(dimethylamino)methyl]benzene (M4, $2.5 \mathrm{~g}, 7.6 \mathrm{mmol})$ in THF $(50 \mathrm{~mL})$ and $\left[\mathrm{Ni}^{0}(\mathrm{COD})_{2}\right]$ $(2.0 \mathrm{~g}, 7.3 \mathrm{mmol})$ in THF $(50 \mathrm{~mL})$. The reaction mixture turned dark-orange at $\pm 0{ }^{\circ} \mathrm{C}$. Volatiles were removed in vacuo and the residue, a dark-brown solid, was dissolved in $\mathrm{CH}_{2} \mathrm{Cl}_{2}$ and precipitated in hexane. The orange product was isolated by filtration, $2.0 \mathrm{~g}, 5.2 \mathrm{mmol}\left(70 \%\right.$ yield). ${ }^{1} \mathrm{H}$ NMR $\left(\mathrm{CD}_{3} \mathrm{OD}\right) \delta$ 2.08 (s, 3H, $\left.\mathrm{CH}_{3} \mathrm{C}(\mathrm{O})\right), 2.65$ (s, 12H, $\mathrm{NCH}_{3}$ ), $3.70\left(\mathrm{~s}, 4 \mathrm{H}, \mathrm{ArCH}_{2}\right.$ ), $6.81(\mathrm{~s}, 2 \mathrm{H}, \mathrm{ArH}) .{ }^{13} \mathrm{C} \mathrm{NMR}\left(\mathrm{CD}_{3} \mathrm{OD}\right) \delta 23.67\left(\mathrm{CH}_{3} \mathrm{C}(\mathrm{O})\right), 51.53$ $\left.\left(\mathrm{NCH}_{3}\right), 73.90(\mathrm{ArCH})_{2}\right), 112.68(\{\mathrm{Ar}\} \mathrm{CH}), 137.29(\{\mathrm{Ar}\} \mathrm{CN}(\mathrm{H}))$, $144.29(\{\mathrm{Ar}\} \mathrm{CNi}), 148.20\left(\{\mathrm{Ar}\} \mathrm{CCH}_{2} \mathrm{~N}\right) 171.48(\mathrm{C}(\mathrm{O}))$. Anal Calcd for $\mathrm{C}_{14} \mathrm{H}_{22} \mathrm{BrN}_{3} \mathrm{NiO}$ : C 43.46; $\mathrm{H} 5.73 ; \mathrm{N} 10.86$. Found: C 43.56 ; H 5.72 ; N 10.74 .

Nickel(II) Complex from 2-Bromo-5-( $N^{\prime}$-propylureido)-1,3bis[(dimethylamino)methyl]benzene (M7). The complex was synthesized according to a literature procedure ${ }^{3,4}$ starting from 2-bromo-5-( $N$ '-propylureido)-1,3-bis[(dimethylamino)methyl]benzene, M5, $(2.0 \mathrm{~g}, 5.39 \mathrm{mmol})$ in THF $(30 \mathrm{~mL})$ and $\left[\mathrm{Ni}^{0}{ }_{-}\right.$ $\left.(\mathrm{COD})_{2}\right](1.4 \mathrm{~g}, 5.1 \mathrm{mmol})$ in THF $(40 \mathrm{~mL})$. At $\pm 10^{\circ} \mathrm{C}$ the reaction mixture turned dark orange. After $4 \mathrm{~h}$ of stirring the reaction mixture was filtered under a nitrogen atmosphere over a G4 glass frit and volatiles were removed in vacuo. The residue, an orange-brown solid, was dissolved in $\mathrm{MeOH}$ (25 $\mathrm{mL}$ ) and filtered over a G4 glass frit. After evaporation of the $\mathrm{MeOH}$ the crude product was redissolved in $\mathrm{CH}_{2} \mathrm{Cl}_{2}$ and precipitated with hexane, affording an orange product, $2.0 \mathrm{~g}$, $4.65 \mathrm{mmol}$ ( $86 \%$ yield). ${ }^{1} \mathrm{H} \mathrm{NMR}\left(\mathrm{CD}_{3} \mathrm{OD}\right) \delta 0.93\left(\mathrm{t}, 3 \mathrm{H}, \mathrm{CH}_{3}\right.$, $\left.{ }^{3} J=7 \mathrm{~Hz}\right), 1.52\left(\mathrm{~m}, 2 \mathrm{H}, \mathrm{CH}_{2}\right), 2.68\left(\mathrm{~s}, 12 \mathrm{H}, \mathrm{NCH}_{3}\right), 3.12(\mathrm{t}$ $\left.2 \mathrm{H}, \mathrm{CH}_{2},{ }^{3} J=7 \mathrm{~Hz}\right), 3.67\left(\mathrm{~s}, 4 \mathrm{H}, \mathrm{ArCH} \mathrm{H}_{2}\right) 6.63(\mathrm{~s}, 2 \mathrm{H}, \mathrm{ArH})$ ${ }^{13} \mathrm{C} \mathrm{NMR}\left(\mathrm{CD}_{3} \mathrm{OD}\right) \delta 11.66\left(\mathrm{CH}_{3}\right), 24.42\left(\mathrm{CH}_{2}\right), 42.66\left(\mathrm{NCH}_{2}\right)$, $51.85\left(\mathrm{NCH}_{3}\right), 74.06\left(\mathrm{ArCH} \mathrm{H}_{2}\right), 112.38(\{\mathrm{Ar}\} \mathrm{CH}), 138.66(\{\mathrm{Ar}\}$ $C \mathrm{~N}), 142.63(\{\mathrm{Ar}\} C \mathrm{Ni}), 148.42\left(\{\mathrm{Ar}\} \mathrm{CCH}_{2} \mathrm{~N}\right), 158.70(\mathrm{CO})$ Anal. Calcd for $\mathrm{C}_{16} \mathrm{H}_{27} \mathrm{BrN}_{4} \mathrm{NiO}$ : C $44.69 ; \mathrm{H} 6.33 ; \mathrm{N} 13.03$. Found: C 44.71; H 6.40; N 12.88 .

Nickel(II) Complex from 5-(N'-Allylureido)-2-bromo-1,3-bis[(dimethylamino)methyl]benzene (M8). The complex was synthesized according to the procedure for M7, starting from 5-( $N^{\prime}$ allylureido)-2-bromo-1,3-bis[(dimethylamino)methyl]benzene (M2, $1.0 \mathrm{~g}, 2.71 \mathrm{mmol})$ in THF $(20 \mathrm{~mL})$ and $\left[\mathrm{Ni}^{\circ}(\mathrm{COD})_{2}\right](0.72$ $\mathrm{g}, 2.61 \mathrm{mmol})$ in THF $(30 \mathrm{~mL})$. After purification an orange solid was obtained, $0.92 \mathrm{~g}, 2.16 \mathrm{mmol}$ ( $80 \%$ yield). ${ }^{1} \mathrm{H}$ NMR
$\left(\mathrm{CD}_{3} \mathrm{OD}\right) \delta 2.64\left(\mathrm{~s}, 12 \mathrm{H}, \mathrm{NCH}_{3}\right), 3.69\left(\mathrm{~s}, 4 \mathrm{H}, \mathrm{ArCH}_{2}\right), 3.78(\mathrm{~m}$, $\left.2 \mathrm{H}, \mathrm{CH}_{2} \mathrm{~N}\right), 5.13\left(\mathrm{~m}, 2 \mathrm{H}, \mathrm{CH}_{2}\right), 5.88(\mathrm{~m}, 1 \mathrm{H}, \mathrm{CH}), 6.65(\mathrm{~s}, 2 \mathrm{H}$, $\mathrm{ArH}) .{ }^{13} \mathrm{C} \mathrm{NMR}\left(\mathrm{CD}_{3} \mathrm{OD}\right) \delta 43.17\left(\mathrm{NCH}_{2}\right), 51.75\left(\mathrm{NCH}_{3}\right), 74.04$ $\left.(\mathrm{ArCH})_{2}\right), 112.45(\{\mathrm{Ar}\} \mathrm{CH}), 115.53\left(\mathrm{CH}_{2}\right), 136.76(\mathrm{CH}), 138.57$ ( $\{\mathrm{ArCN}), 143.00(\{\mathrm{Ar}\} C \mathrm{Ni}), 148.42\left(\{\mathrm{Ar}\} C \mathrm{CH}_{2} \mathrm{~N}\right), 158.44(\mathrm{CO})$. Anal. Calcd for $\mathrm{C}_{16} \mathrm{H}_{25} \mathrm{BrN}_{4} \mathrm{NiO}$ : C $44.90 ; \mathrm{H}$ 5.89; $\mathrm{N} 13.09$. Found: C 45.01; H 5.98; N 12.89 .

Synthesis of Polymers. Poly((2-carboxyethyl)methylsiloxane) (P1). This polymer was synthesized as a viscous milkywhite oil according to a literature procedure ${ }^{6}$ starting from (2cyanoethyl)methyldichlorosilane. IR $\left(\mathrm{NaCl}, \mathrm{cm}^{-1}\right) 1710(\mathrm{C}=\mathrm{O})$, 1000-1100 ( $\mathrm{Si}-\mathrm{O}-\mathrm{Si})$. Anal. Calcd for $\mathrm{H}\left(\mathrm{C}_{4} \mathrm{H}_{8} \mathrm{O}_{3} \mathrm{Si}\right)_{n} \mathrm{OH}$ : C 36.34; H 6.11. Found: C 34.25; H 6.17. Since the characterization of poly((2-carboxyethyl)methylsiloxane) (P1) is difficult, its methyl ester (P2), a colorless liquid, was synthesized by adding $\mathrm{MeOH}$ to a small amount of $\mathbf{P 1}$, and analysis of this proved that complete conversion of all cyano groups to carboxylic acid groups had taken place. Analysis of P2: ${ }^{1} \mathrm{H}$ NMR $\left(\mathrm{CDCl}_{3}\right) \delta 0.09\left(\mathrm{~m}, 3 \mathrm{H}, \mathrm{Si}-\mathrm{CH}_{3}\right), 0.84\left(\mathrm{~m}, 2 \mathrm{H}, \mathrm{Si}-\mathrm{CH}_{2}\right), 2.29$ $\left(\mathrm{m}, 2 \mathrm{H}, \mathrm{CH}_{2} \mathrm{C}(\mathrm{O})\right), 3.61$ (s, $\left.3 \mathrm{H}, \mathrm{C}(\mathrm{O}) \mathrm{OCH}_{3}\right) .{ }^{13} \mathrm{C} \mathrm{NMR}\left(\mathrm{CDCl}_{3}\right)$ $\delta-0.84\left(\mathrm{Si}-\mathrm{CH}_{3}\right), 11.78,11.83,11.89,12.03\left(\mathrm{Si}-\mathrm{CH}_{2}\right), 27.54$, $27.61\left(\mathrm{CH}_{2} \mathrm{C}(\mathrm{O})\right), 51.6\left(\mathrm{C}(\mathrm{O}) \mathrm{OCH}_{3}\right), 174.88(\mathrm{C}(\mathrm{O}))$. ${ }^{29} \mathrm{Si} \mathrm{NMR}$ $\left(\mathrm{CDCl}_{3}\right) \delta-20.0\left(\mathrm{br}\right.$, cyclic $\left.[\mathrm{MeRSiO}]_{n}\right),-22.3(\mathrm{br}$, linear $\left.[\mathrm{MeRSiO}]_{n}\right)$. IR $\left(\mathrm{NaCl}, \mathrm{cm}^{-1}\right) 1740(\mathrm{C}=\mathrm{O}), 1000-1100(\mathrm{Si}-$ O-Si). GPC: $M_{\mathrm{w}}=22500, M_{\mathrm{n}}=11000, M_{\mathrm{w}} / M_{\mathrm{n}}=2.0$. Anal. Calcd for $\mathrm{H}\left(\mathrm{C}_{5} \mathrm{H}_{10} \mathrm{O}_{3} \mathrm{Si}\right)_{n} \mathrm{OH}$ : C $41.07 ; \mathrm{H} \mathrm{6.89}$. Found: $\mathrm{C} 41.17$; $\mathrm{H} 6.91$.

Poly[(2-(chlorocarbonyl)ethyl)methylsiloxane](P3). This polymer was synthesized according to a literature procedure. ${ }^{6}$ IR $\left(\mathrm{NaCl}, \mathrm{cm}^{-1}\right) 1800(\mathrm{C}=\mathrm{O}), 1000-1100(\mathrm{Si}-\mathrm{O}-\mathrm{Si})$

General Procedure for the Functionalization of Polyl(2(chlorocarbonyl)ethyl)methylsiloxane] (P3). To a stirred solution of $\mathbf{P 3}$ and $\mathrm{Et}_{3} \mathrm{~N}$ in $\mathrm{CH}_{2} \mathrm{Cl}_{2}$ under a nitrogen atmosphere was added dropwise an aniline derivative, while the reaction temperature was maintained at $20^{\circ} \mathrm{C}$ with a cold water bath. After addition the reaction mixture was stirred for an additional $16 \mathrm{~h}$ at ambient temperature. Subsequently, the reaction mixture was filtered, and to the filtrate was added $\mathrm{MeOH}$. After stirring this mixture for $1 \mathrm{~h}$ volatiles were removed by rotary evaporation and the residue dissolved in $\mathrm{CH}_{2} \mathrm{Cl}_{2}$. The $\mathrm{CH}_{2} \mathrm{Cl}_{2}$ solution was washed twice with $1 \mathrm{M}$ $\mathrm{NaOH}$ and twice with brine, dried over $\mathrm{MgSO}_{4}$, and evaporated to dryness. The crude product was dissolved in a small amount of $\mathrm{CH}_{2} \mathrm{Cl}_{2}$ and precipitated as a solid with hexane. After washing the precipitate twice with hexane and drying in vacuo, the polymer was obtained as a pale yellow foam. This precipitation procedure was then repeated.

Polymer P5 from Reaction of P3 with Aniline. Polymer P5 was synthesized according to the general procedure. P3 (0.93 g) in $\mathrm{CH}_{2} \mathrm{Cl}_{2}(20 \mathrm{~mL})$ was mixed with $\mathrm{Et}_{3} \mathrm{~N}(2 \mathrm{~mL})$. Subsequently aniline $(0.61 \mathrm{~g}, 0.60 \mathrm{~mL}, 6.58 \mathrm{mmol})$ was added dropwise. The product was isolated as a pale yellow foam in $0.96 \mathrm{~g}$ yield. ${ }^{1} \mathrm{H}$ NMR $\left(\mathrm{CDCl}_{3}\right) \delta 0.08\left(\mathrm{br}, \mathrm{Si}-\mathrm{CH}_{3}\right), 0.98(\mathrm{br}$, $\left.\mathrm{Si}-\mathrm{CH}_{2}\right), 2.42\left(\mathrm{br}, \mathrm{CH}_{2} \mathrm{C}(\mathrm{O})\right), 7.00,7.19,7.52(\mathrm{br}, \mathrm{ArH}) .{ }^{13} \mathrm{C}$ NMR $\left(\mathrm{CDCl}_{3}\right) \delta-0.51\left(\mathrm{Si}-\mathrm{CH}_{3}\right), 8.57\left(\mathrm{Si}-\mathrm{CH}_{2}\right), 30.90\left(\mathrm{CH}_{2} \mathrm{C}-\right.$ (O)), 120.15 ( $\{\mathrm{Ar}\} \mathrm{CH}$, ortho), 124.07 ( $\{\mathrm{Ar}\} \mathrm{CH}$, para) 128.77 ( $\{\mathrm{Ar}\} \mathrm{CH}$, meta), $138.32(\{\mathrm{Ar}\} \mathrm{CN}), 173.76(C(\mathrm{O})) .{ }^{29} \mathrm{Si} \mathrm{NMR}$ $\left(\mathrm{CDCl}_{3}\right) \delta-20.0\left(\mathrm{br}\right.$, cyclic compound $\left.[\mathrm{MeRSiO}]_{n}\right),-21.9(\mathrm{br}$, linear $\left.[\mathrm{MeRSiO}]_{n}\right)$. IR $\left(\mathrm{NaCl}, \mathrm{cm}^{-1}\right) 3000-3310(\mathrm{NH}), 1670$ $(\mathrm{C}=\mathrm{O}), 1260\left(\mathrm{CH}_{3}-\mathrm{Si}, \mathrm{CH}_{2}-\mathrm{Si}\right), 1000-1100(\mathrm{Si}-\mathrm{O}-\mathrm{Si})$.

Polymer P4 from Reaction of P3 with M1. Polymer P4 was synthesized according to the above general procedure. $\mathbf{P 3}$ $(1.14 \mathrm{~g})$ in $\mathrm{CH}_{2} \mathrm{Cl}_{2}(40 \mathrm{~mL})$ was mixed with $\mathrm{Et}_{3} \mathrm{~N}(5 \mathrm{~mL})$. Subsequently, aryl bromide $\mathbf{M 1}(2.25 \mathrm{~g}, 7.86 \mathrm{mmol})$ was added dropwise. The product was isolated as a pale yellow foam in 3.00 g yield. ${ }^{1} \mathrm{H}$ NMR $\left(\mathrm{CDCl}_{3}\right) \delta 0.05\left(\mathrm{br}, \mathrm{Si}-\mathrm{CH}_{3}\right), 0.92(\mathrm{br}$, $\mathrm{Si}-\mathrm{CH}_{2}$ ), 2.21 (br, $\mathrm{NCH}_{3}$ ), $2.42\left(\mathrm{br}, \mathrm{CH}_{2} \mathrm{C}(\mathrm{O})\right.$ ), $3.48\left(\mathrm{br}, \mathrm{ArCH}_{2}\right.$ ), $3.62\left(\mathrm{br}, \mathrm{C}(\mathrm{O}) \mathrm{OCH}_{3}\right), 7.61(\mathrm{ArH}) .{ }^{13} \mathrm{C} \mathrm{NMR}\left(\mathrm{CDCl}_{3}\right) \delta-0.63$ $\left(\mathrm{Si}-\mathrm{CH}_{3}\right), 10.53\left(\mathrm{Si}-\mathrm{CH}_{2}\right.$ of methyl ester part $), 12.43\left(\mathrm{Si}-\mathrm{CH}_{2}\right)$, $27.61\left(\mathrm{CH}_{2} \mathrm{C}(\mathrm{O}) \mathrm{O}\right), 30.64\left(\mathrm{CH}_{2} \mathrm{C}(\mathrm{O}) \mathrm{N}\right), 45.38\left(\mathrm{NCH}_{3}\right), 50.06$ $\left(\mathrm{C}(\mathrm{O}) \mathrm{OCH}_{3}\right), 63.65\left(\mathrm{ArCH}{ }_{2}\right), 120.98,121.24(\{\mathrm{Ar}\} \mathrm{CH}$ and $\{\mathrm{Ar}\}-$ $\mathrm{CBr}), 137.67,138.56$ ( $\{\mathrm{Ar}\} \mathrm{CN}$ and $\left.\{\mathrm{Ar}\} \mathrm{CCH}_{2} \mathrm{~N}\right), 172.84(\mathrm{C}(\mathrm{O})$ ). ${ }^{29} \mathrm{Si} \mathrm{NMR}\left(\mathrm{CDCl}_{3}\right) \delta-19.9(\mathrm{br} \text {, cyclic compound [MeRSiO] }]_{n}$ ), -21.9 (br, linear $\left.[\mathrm{MeRSiO}]_{n}\right)$. IR $\left(\mathrm{NaCl}, \mathrm{cm}^{-1}\right): 3000-3320$ $(\mathrm{NH}), 2770 / 2820 / 2860\left(\mathrm{~N}\left(\mathrm{CH}_{3}\right)_{2}\right), 1670(\mathrm{C}=\mathrm{O}), 1260\left(\mathrm{CH}_{3}-\mathrm{Si}\right.$, 
Table 4. Experimental Data for Incorporation of Nickel in P4 and Elemental Analysis Data for the Resulting Polymers P6a-e

\begin{tabular}{|c|c|c|c|c|c|c|c|}
\hline \multirow[b]{2}{*}{ polymer } & \multirow{2}{*}{$\begin{array}{c}\mathbf{P 4} \\
(\mathbf{m g})\end{array}$} & \multirow{2}{*}{$\begin{array}{l}\mathrm{Ni}^{0}(\mathrm{COD})_{2} \\
\quad(\mathrm{mg})\end{array}$} & \multirow{2}{*}{$\begin{array}{c}\text { total } \\
\text { THF (mL) }\end{array}$} & \multicolumn{4}{|c|}{$\begin{array}{l}\text { Elemental analysis } \\
\text { found (\%) }\end{array}$} \\
\hline & & & & $\mathrm{C}$ & $\overline{\mathrm{H}}$ & $\bar{N}$ & $\mathrm{Ni}$ \\
\hline P6 & 50 & & 60 & 42.0 & 6.18 & 7.5 & 5.2 \\
\hline P6 & 1000 & & 150 & 16 & 6.23 & 6.4 & 9.6 \\
\hline P6 & 600 & & 60 & 42.69 & 6.40 & 7.36 & 4.55 \\
\hline & 6 & & & & 6.30 & 7.55 & 5.46 \\
\hline $\mathbf{P}$ & 1000 & 800 & 120 & 42.29 & 6.06 & 7.64 & 10.37 \\
\hline
\end{tabular}

$\left.\mathrm{CH}_{2}-\mathrm{Si}\right), 1000-1100(\mathrm{Si}-\mathrm{O}-\mathrm{Si})$. GPC: $M_{\mathrm{w}}=1670, M_{\mathrm{n}}=740$, $M_{\mathrm{w}} / M_{\mathrm{n}}=2.2$.

Polymers P6a-e from P4; Incorporation of Nickel. The incorporation of nickel into the immobilized ligand system 4-anchored-2,6-bis[(dimethylamino)methyl]phenyl bromide was performed under a nitrogen atmosphere according to a modified literature procedure. ${ }^{2 a}$ To a stirred solution of $\left[\mathrm{Ni}^{0}(\mathrm{COD})_{2}\right]$ in THF was added a solution of P4 in THF at $-78{ }^{\circ} \mathrm{C}$. Subsequently, the temperature of the reaction mixture was slowly raised to $0{ }^{\circ} \mathrm{C}$. At this temperature the reaction mixture changed from a yellow suspension to a brown-orange solution. After the reaction mixture was stirred for an additional $2 \mathrm{~h}$ at $0{ }^{\circ} \mathrm{C}$ the mixture was concentrated in vacuo to one-third of its original volume and the solution was filtered over a G4 glass frit. Concentrating the filtrate at this temperature in vacuo afforded the crude product $\mathbf{P 6 a}-\mathbf{e}$. This was purified by several precipitations from $\mathrm{CH}_{2} \mathrm{Cl}_{2}$ solutions with hexane. Filtration of the precipitate afforded a pale brown product, which was dried in vacuo. P6a-e: ${ }^{1} \mathrm{H}$ NMR $\left(\mathrm{CD}_{3} \mathrm{OD}\right) \delta 0.15$ (br, $\mathrm{Si}-\mathrm{CH}_{3}$ ), $0.92\left(\mathrm{br} \mathrm{m}, \mathrm{Si}-\mathrm{CH}_{2}\right), 2.21$ (br, $\mathrm{NCH}_{3}$ of the "free" ligand), $2.40\left(\mathrm{br}, \mathrm{CH}_{2} \mathrm{C}(\mathrm{O})\right.$ ), $2.68\left(\mathrm{br}, \mathrm{NCH}_{3}\right.$ of the nickel complex) $3.60\left(\mathrm{br}, \mathrm{ArCH} \mathrm{H}_{2}\right.$ and $\left.\mathrm{C}(\mathrm{O}) \mathrm{OCH}_{3}\right), 6.80(\mathrm{ArH}$ of the nickel complex), 7.61 (ArH of the "free" ligand). ${ }^{13} \mathrm{C} \mathrm{NMR}\left(\mathrm{CD}_{3}\right.$ OD) $\delta 0.00\left(\mathrm{Si}-\mathrm{CH}_{3}\right), 11.95\left(\mathrm{Si}-\mathrm{CH}_{2}\right.$ of methyl ester part), $13.35\left(\mathrm{Si}-\mathrm{CH}_{2}\right), 28.79\left(\mathrm{CH}_{2} \mathrm{C}(\mathrm{O}) \mathrm{O}\right), 31.44\left(\mathrm{CH}_{2} \mathrm{C}(\mathrm{O}) \mathrm{N}\right), 45.61$ $\left(\mathrm{NCH}_{3}\right.$ of the "free" ligand), $51.40\left(\mathrm{NCH}_{3}\right.$ of the nickel complex), 64.55 $\left(\mathrm{ArCH}_{2}\right.$ of the "free" ligand), $74.09\left(\mathrm{ArCH}_{2}\right.$ of the nickel complex), 112.80 ( $\{\mathrm{Ar}\} \mathrm{CH}$ of the nickel complex), 121.98, 123.05 ( $\{\mathrm{Ar}\} \mathrm{CH}$ of the "free" ligand and $\{\mathrm{Ar}\} \mathrm{CBr}$ ), 137.34, $138.89,139.45\left(\{\mathrm{Ar}\} \mathrm{CCH}_{2} \mathrm{~N},\{\mathrm{Ar}\} \mathrm{CN}\right.$ of the "free" ligand and of the nickel complex), 148,00 ( $\{\mathrm{Ar}\} C \mathrm{Ni}), 174.39(\mathrm{C}(\mathrm{O})$ ). IR $\left(\mathrm{KBr}, \mathrm{cm}^{-1}\right): 3000-3340(\mathrm{NH}), 2770 / 2820 / 2860\left(\mathrm{~N}\left(\mathrm{CH}_{3}\right)_{2}\right), 1680$ $(\mathrm{C}=\mathrm{O}), 1260\left(\mathrm{CH}_{3}-\mathrm{Si}, \mathrm{CH}_{2}-\mathrm{Si}\right), 1000-1100(\mathrm{Si}-\mathrm{O}-\mathrm{Si})$. Further experimental and elemental analysis data are to be found in Table 4.

Synthesis of the Polysiloxanes P8 and P9. General Procedure for the Functionalization of Organohydrosiloxane
Copolymer P7. A compound containing an $N^{\prime}$-allylureido functionality $\mathbf{M 2}$ or $\mathbf{M 3}(0.9 \mathrm{~mol}$ equiv with respect to $\mathrm{Si}-\mathrm{H}$ groups of the copolymer) and polysiloxane copolymer P7 (see Scheme 2) were dissolved in toluene. The mixture was heated to $80^{\circ} \mathrm{C}$ under a nitrogen atmosphere and $\mathrm{H}_{2} \mathrm{PtCl}_{6}(0.01 \mathrm{~mol}$ equiv) in isopropyl alcohol or methanol was then added with a syringe. The reaction mixture was heated until IR analysis showed that all $\mathrm{Si}-\mathrm{H}$ stretch vibrations had disappeared and all volatiles were then removed in vacuo. The remaining viscous oil was dissolved in $\mathrm{CH}_{2} \mathrm{Cl}_{2}$ and washed twice with 1 $\mathrm{M} \mathrm{NaOH}$ solution and twice with $\mathrm{H}_{2} \mathrm{O}$. The organic layer was dried over $\mathrm{MgSO}_{4}$ and concentrated by rotary evaporation. Subsequently, the polymer was isolated by preparative GPC (Biorad SX-1 with $\mathrm{CH}_{2} \mathrm{Cl}_{2}$ as eluent).

Polysiloxane $P 8$. The polymer was synthesized according to the above general procedure. 5-( $N^{\prime}$-Allylureido)-2-bromo1,3-bis[(dimethylamino)methyl]benzene $(3.45 \mathrm{~g}, 9.35 \mathrm{mmol})$ and polysiloxane copolymer $\mathbf{P 7}$ ( $1.37 \mathrm{~g}$, estimated $10.0 \mathrm{mmol}$ $\mathrm{Si}-\mathrm{H})$ were dissolved in toluene $(80 \mathrm{~mL})$. After 6 days reaction time all $\mathrm{Si}-\mathrm{H}$ stretch vibrations had disappeared. The product was isolated as a viscous yellow oil in $1.35 \mathrm{~g}$ yield. ${ }^{1} \mathrm{H}$ NMR $\left(\mathrm{CDCl}_{3}\right) \delta 0.02\left(\mathrm{br}, \mathrm{Si}-\mathrm{CH}_{3}\right), 0.50\left(\mathrm{br}, \mathrm{Si}-\mathrm{CH}_{2}\right), 1.55\left(\mathrm{br}, \mathrm{CH}_{2}\right)$, $2.23\left(\mathrm{br}, \mathrm{NCH}_{3}\right), 3.18\left(\mathrm{br}, \mathrm{CH}_{2} \mathrm{~N}\right), 3.45\left(\mathrm{br}, \mathrm{ArCH}_{2}\right.$ and $\mathrm{OCH}_{3}$ ), 7.38 (br, $\mathrm{ArH}) .{ }^{13} \mathrm{C} \mathrm{NMR}\left(\mathrm{CDCl}_{3}\right) \delta-8.24$ to $1.53\left(\mathrm{Si}-\mathrm{CH}_{3}\right)$, $14.54\left(\mathrm{Si}-\mathrm{CH}_{2}\right), 23.72\left(\mathrm{CH}_{2}\right), 42.80\left(\mathrm{CH}_{2} \mathrm{~N}\right), 45.21\left(\mathrm{NCH}_{3}\right)$, 53.35 $\left(\mathrm{OCH}_{3}\right), 63.57\left(\mathrm{ArCH} \mathrm{H}_{2}\right), 119.07(\{\mathrm{Ar}\} \mathrm{CBr}), 120.42(\{\mathrm{Ar}\}-$ $C \mathrm{H}), 138.25\left(\{\mathrm{Ar}\} \mathrm{CCH}_{2} \mathrm{~N}\right), 138.36(\{\mathrm{Ar}\} \mathrm{CN}), 156.35(\mathrm{CO})$. Anal. Calcd for $\mathbf{P 8}$ with $30 \%$ reaction of $\mathrm{Si}-\mathrm{H}$ with double bonds: C $38.89 ; \mathrm{H} 7.47 ; \mathrm{N} 5.73 ; \mathrm{Br} 8.18$. Found: C $38.72 ; \mathrm{H}$ $7.31 ; \mathrm{N} 5.90 ; \mathrm{Br} 8.52$.

Polysiloxane P9. This polymer was synthesized according to the general procedure described above. 5-( $N^{\prime}$-Allylureido $)$ benzene M3 $(0.39 \mathrm{~g}, 2.2 \mathrm{mmol})$ and polysiloxane copolymer P7 $(0.34 \mathrm{~g}$, estimated $2.5 \mathrm{mmol} \mathrm{Si-H}$ groups) were dissolved in toluene $(20 \mathrm{~mL})$. After $19 \mathrm{~h}$ reaction time all $\mathrm{Si}-\mathrm{H}$ stretch vibrations had disappeared. After isolation a viscous yellow oil was obtained in 0.14 g yield. ${ }^{13} \mathrm{C} \mathrm{NMR}\left(\mathrm{CDCl}_{3}\right) \delta-3.41$ to $1.75\left(\mathrm{Si}-\mathrm{CH}_{3}\right), 14.63\left(\mathrm{Si}-\mathrm{CH}_{2}\right), 23.76\left(\mathrm{CH}_{2}\right), 25.48\left(\mathrm{CH}_{3}\right.$, isopropyl), $42.76\left(\mathrm{CH}_{2} \mathrm{~N}\right), 64.84(\mathrm{OCH}, i-\mathrm{Pr}), 119.46(\{\mathrm{Ar}\} \mathrm{CH}$, ortho), 122.44 ( $\{\mathrm{Ar}\} \mathrm{CH}$, para), 128.92 ( $\{\mathrm{Ar}\} \mathrm{CH}$, meta), 139.47 ( $\{\mathrm{Ar}\} \mathrm{CN}), 156.47(\mathrm{CO})$.

Acknowledgment. We would like to thank Mr. B. H. A. Maas, Mr. S. Krol, Mr. J. P. C. van Nispen, and Mr. L. M. Visser for their contributions to the synthetic part of this research. 